\title{
Feeding colostrum or a 1:1 colostrum:milk mixture for 3 days postnatal increases small intestinal development and minimally influences plasma glucagon-like peptide-2 and serum insulin-like growth factor-1 concentrations in Holstein bull calves
}

\author{
J. Pyo, ${ }^{1} \odot$ K. Hare, ${ }^{2}$ S. Pletts, ${ }^{1} \oplus$ Y. Inabu, ${ }^{3}$ D. Haines,${ }^{4}$ T. Sugino, ${ }^{3} \oplus$ L. L. Guan, ${ }^{1} \oplus$ and M. Steele ${ }^{2 *} \oplus$ \\ ${ }^{1}$ Department of Agricultural, Food and Nutritional Science, Faculty of Agricultural, Life and Environmental Sciences, University of Alberta, \\ Edmonton, AB, Canada T6G 2P5 \\ ${ }^{2}$ Department of Animal Biosciences, Animal Science and Nutrition, University of Guelph, Guelph, ON, Canada N1G 1Y2 \\ ${ }^{3}$ The Research Center for Animal Science, Graduate School of Biosphere Science, Hiroshima University, Higashi-Hiroshima, Japan $739-8528$ \\ ${ }^{4}$ The Saskatoon Colostrum Company Ltd., Saskatoon, SK, Canada S7K 6A2
}

\begin{abstract}
This study evaluated how feeding colostrum- or a colostrum-milk mixture for $3 \mathrm{~d}$ postnatal affects plasma glucagon-like peptide-2 (GLP-2), serum insulin-like growth factor-1 (IGF-1), and small intestinal histomorphology in calves. Holstein bulls $(\mathrm{n}=24)$ were fed colostrum at $2 \mathrm{~h}$ postnatal and randomly assigned to receive either colostrum (COL), whole milk (WM), or a 1:1 COL:WM mixture (MIX) every $12 \mathrm{~h}$ from 12 to $72 \mathrm{~h}$. A jugular venous catheter was placed at 1 $\mathrm{h}$ postnatal to sample blood frequently for the duration of the experiment. Samples were collected at 1, 2, 3, 6, 9, 11, and $12 \mathrm{~h}$. Following the 12-h meal, blood was collected at half-hour intervals until $16 \mathrm{~h}$ and then at 1-h intervals from 16 to $24 \mathrm{~h}$. A 27 -h sample was taken, then blood was sampled every $6 \mathrm{~h}$ from 30 to $60 \mathrm{~h}$. Again, blood was taken at half-intervals from 60 to $64 \mathrm{~h}$, then at 65 and $66 \mathrm{~h}$, following which, a 2-h sampling interval was used until $72 \mathrm{~h}$. Plasma GLP-2 (all time points) and serum IGF-1 (at time points: 1, $6,12,18,24,36,48$, and $72 \mathrm{~h}$ ) were both analyzed. Duodenal, jejunal, and ileal tissues were collected at $75 \mathrm{~h}$ of age to assess histomorphology and cellular proliferation. Feeding COL, rather than WM, increased plasma GLP-2 by $60 \%$ for $2 \mathrm{~h}$ and tended to increase GLP-2 by $49.4 \%$ for $4 \mathrm{~h}$ after the 60 -h meal. Insulinlike growth factor-1 area under the curve (from 12 to $72 \mathrm{~h}$ ) tended to be $27 \%$ greater for COL than WM calves but was otherwise unaffected by treatment. Ileal crypts tended to proliferate more with MIX than WM, whereas ileal crypt proliferation did not differ for COL compared with MIX or WM and was not different between treatments in the proximal jejunum. Villi
\end{abstract}

Received July 5, 2019.

Accepted January 5, 2020.

*Corresponding author: masteele@uoguelph.ca height was increased 1.8 and $1.5 \times(\mathrm{COL}$ and MIX vs. $\mathrm{WM}$ ) in the proximal and distal jejunum, respectively, whereas MIX duodenal and ileal villi height tended to be 1.5 and $1.4 \times$ that of WM. Crypt depth did not differ in any region. Surface area of the gastrointestinal tract was reduced for WM by 60 and $58 \%$ (proximal jejunum) and 38 and $52 \%$ (ileum) relative to COL and MIX and was $54 \%$ less than MIX in the distal jejunum. Overall, extended COL feeding minimally increased plasma GLP-2 and serum IGF-1 compared with WM feeding. As COL and MIX similarly promoted small intestinal maturation, feeding calves transition milk to promote intestinal development could be a strategy for producers.

Key words: colostrum, glucagon-like peptide-2, insulin-like growth factor-1, histomorphology

\section{INTRODUCTION}

The gastrointestinal tract (GIT) of neonatal ruminants rapidly matures after birth (Blum and Hammon, 2000; Guilloteau et al., 2009) as it adjusts to absorbing the orally provided nutrients necessary to meet the high energy and protein requirements of the neonatal phase (Davis et al., 1996). Most producers offer colostrum for the first day postnatal (Shivley et al., 2018; Winder et al., 2018), after which only milk or milk replacer is fed. The calf is deprived of the nonnutritive, bioactive fraction of transition milk (milkings 2 to 6 ; Blum and Hammon, 2000) that could further intestinal maturation while simultaneously being provided a diet that contains less energy and protein (Blum and Hammon, 2000). As such, the neonatal calf may receive inadequate nutrients and have suboptimal intestinal development. Feeding colostrum for an extended period of time does increase preprandial calf plasma glucose and total protein (Steinhoff-Wagner et al., 2011), an effect that is partially attributed to improved GIT 
development (Bühler et al., 1998; Steinhoff-Wagner et al., 2014; Yang et al., 2015). Similarly, transition milk or colostrum-milk mixes are more beneficial to GIT development than milk or whole milk feeding (Bühler et al., 1998; Yang et al., 2015). Although prolonged colostrum feeding may be more beneficial than transition milk feeding (Steinhoff-Wagner et al., 2014; Yang et al., 2015), it is important to note that prior research has not characterized the neonatal gut response to the natural transition from colostrum to whole milk by providing a primary meal of colostrum in advance of transition or whole milk.

Numerous nonnutritive bioactive peptides and hormones are present in colostrum and transition milk (Blum and Hammon, 2000; McGrath et al., 2016) to stimulate postnatal development of the neonatal calf gastrointestinal tract (Blum and Hammon, 2000). Notably, IGF-1 is one of the most abundant bioactive factors present in colostrum (Blum and Hammon, 2000; McGrath et al., 2016) and is known to promote small intestinal maturation (Burrin et al., 1996; Georgiev et al., 2003). Colostrum consumption may potentiate a positive feedback cycle by which local endocrine cascades are stimulated and promote GIT maturation. For instance, glucagon-like peptide (GLP)-2 can enhance the mitogenic action of IGF-1 to synergistically benefit GIT development, as demonstrated in rodent species (Dubé et al., 2006; Rowland et al., 2011; Leen et al., 2011). Glucagon-like peptide-2 has not been identified in colostrum (Petersen et al., 2003). However, it is co-secreted intra-luminally with GLP-1 after feeding (Burrin et al., 2003a,b), and as colostrum consumption stimulates GLP-1 secretion in neonatal calves (Inabu et al., 2018, 2019), it is likely that GLP-2 is similarly released and may cooperate with IGF-1 to promote small intestinal development. To the authors' knowledge, the relationship between small intestinal development, IGF-1, and GLP-2 has not been characterized in neonatal calves. However, Inabu et al. (2019) reported that calves fed colostrum for $3 \mathrm{~d}$ rather than milk had increased plasma GLP-1, but only on d 3 postnatal when they were compared with counterparts that consumed a colostrum-milk mixture (Inabu et al., 2019). Because GLP-2 is co-secreted with GLP-1 (Burrin et al., 2003a,b), the work of Inabu et al. (2019) suggests that that extended colostrum feeding may stimulate GLP-2 release, thereby promoting intestinal development.

The objective of the study was to determine if feeding colostrum, a mixture of colostrum and whole milk, or only whole milk after an initial colostrum meal influences GIT histomorphology and plasma GLP-2 and serum IGF-1 concentrations in neonatal Holstein calves. It was hypothesized that feeding colostrum for
$3 \mathrm{~d}$ would benefit GIT development and elevate serum IGF-1 and GLP-2 concentrations more than feeding a mixture of colostrum and whole milk or only whole milk.

\section{MATERIALS AND METHODS}

Experiment design and procedures used in this study were approved by the Animal Care and Use Committee (University of Alberta, AUP00001595) before the start of the experiment. The current study was performed in conjunction with Inabu et al. (2019), in which experimental design have been previously described. As such, they will be briefly detailed here.

\section{Animal Husbandry and Feeding}

This experiment was conducted in the Dairy Research and Technology Centre at the University of Alberta. Holstein bull calves ( $\mathrm{n}=24$; birth BW: 35 to $55 \mathrm{~kg}$ ) were removed from their dam immediately following parturition and transferred into clean, plastic-paneled, calf pens $(1.2 \times 1.8 \mathrm{~m})$ bedded with fresh shavings and straw. The standard birth care protocol was to stimulate calves for 20 min postnatal by drying them with clean towels and to sanitize their navel using a $7 \%$ iodine solution. Pooled and pasteurized colostrum (62 g of IgG/L) was supplied by Saskatoon Colostrum Company Ltd. (Saskatoon, SK, Canada) and fed (7.5\% BW) to all calves at $2 \mathrm{~h}$ postnatal by bottle. The colostrum was thawed and warmed to precisely $39^{\circ} \mathrm{C}$ in a water bath before feeding. The same meal preparation protocol was used for the remaining meals. Before the experiment it was determined that 8 calves per treatment were required to detect a $20 \%$ difference in gastrointestinal measurements with an $80 \%$ statistical power (Berndtson, 1991). Following the first colostrum feeding, calves were randomly assigned to 1 of 3 treatments: colostrum $(\mathbf{C O L} ; \mathrm{n}=8, \mathrm{BW}=41.5 \pm 3.3 \mathrm{~kg})$, a 1:1 mixture of colostrum and whole milk $(\mathbf{M I X} ; \mathrm{n}=8$, $\mathrm{BW}=39.8 \pm 3.3 \mathrm{~kg}$ ), or whole milk (WM; $\mathrm{n}=8$, BW $=43.3 \pm 3.3 \mathrm{~kg})$. The colostrum fed in the COL and MIX treatments was the same supply of colostrum that was fed at $2 \mathrm{~h}$. The whole milk fed in the MIX and WM treatments was pooled from cows at the Dairy Research and Technology Center (University of Alberta, Edmonton, AB, Canada) before the start of the experiment. For both colostrum and whole milk, a single batch was prepared and stored in bags frozen at $-20^{\circ} \mathrm{C}$ until use to ensure that nutrient compositions and provisions were consistent within treatments. The batches were analyzed before the start of the study by the Central Milk Testing laboratory (Dairy Herd Improvement, Edmonton, AB, Canada) for fat, protein, lactose, and 
urea-N. Colostrum and whole milk were freeze-dried and DM (\%) was calculated from the weight of the dried sample as a proportion of the wet sample weight. Colostrum IGF-1 was analyzed using a commercially available immunoassay kit (DRG IGF-1 600 ELISA, DRG International Inc., Springfield Township, NJ) by the Saskatoon Colostrum Company Ltd. (Saskatoon, SK, Canada). The DM, macronutrient, and IGF-1 composition of COL, MIX, and WM treatments is shown in Table 1. Meals were offered by bottle $\left(5 \% \mathrm{BW}, 39^{\circ} \mathrm{C}\right)$ at 12-h intervals from 12 until $72 \mathrm{~h}$ after birth. If they were not consumed within $30 \mathrm{~min}$, the refusal was fed using an esophageal tube. Calves that consecutively refused their full meal twice were removed from the study, and as a result, 4 calves were removed from the study. Two had been assigned to COL and the other 2 had been assigned to MIX and WM. The study continued until the necessary number of replicates $(n=8 /$ treatment) were attained. All calves achieved adequate passive transfer (maximum concentration: $\mathrm{COL}=30.4$ $\pm 1.3 \mathrm{~g} \mathrm{IgG} / \mathrm{L} ; \mathrm{MIX}=27.2 \pm 1.3 \mathrm{~g} \operatorname{IgG} / \mathrm{L} ; \mathrm{WM}=23.9$ $\pm 1.3 \mathrm{~g} \mathrm{IgG/L)}$.

\section{Jugular Catheterization and Blood Sampling}

To facilitate ease of blood collection and reduce the stress response associated with repeated jugular venipuncture, calves underwent jugular catheterization (Fischer et al., 2018) at $1 \mathrm{~h}$ after birth using a 2 inch $(5.08 \mathrm{~cm}), 16$-gauge i.v. catheter (Terumo Medical Corporation, Somerset, NJ) fitted with a catheter extension line. Baseline blood samples were taken at birth, in conjunction with catheterization, and then at $2,3,6$, and $9 \mathrm{~h}$ postnatal. An intensive postprandial sampling period (12 h in length), in which blood was sampled every $30 \mathrm{~min}$ for $4 \mathrm{~h}$, was initiated at $12 \mathrm{~h}$ (first treatment meal). After $16 \mathrm{~h}$, blood was collected at 60-min intervals until the sampling period was completed. One sample was then taken at $27 \mathrm{~h}$, whereas the following samples were collected at 6 -h intervals from 30 to 60 $\mathrm{h}$. The second intensive postprandial sampling period began at $60 \mathrm{~h}$ (fifth treatment meal; 30-min sampling intervals for $4 \mathrm{~h}$ ). After the 65 and $66 \mathrm{~h}$ samplings, the collection interval was lengthened to 120 min until the sampling was completed at $72 \mathrm{~h}$. All collections that coincided with feedings were performed before the meals were fed. The total volume of blood collected $(\mathrm{BW}>43 \mathrm{~kg}=10 \mathrm{~mL} /$ collection, $\mathrm{BW}<43 \mathrm{~kg}=8$ $\mathrm{mL} /$ collection) per calf in one day did not exceed $1 \%$ of BW as per Animal Care regulations at the University of Alberta. The catheter and extension lines were flushed with $6 \mathrm{~mL}$ of saline and $1.5 \mathrm{~mL}$ of heparinized saline $(20 \mathrm{IU} / \mathrm{mL}$ heparin, Fresenius Kabi, Toronto, ON, Canada) after each collection to prevent the formation of blood clots within the catheter. Blood was collected in $10-\mathrm{mL}$ syringes and transferred into vials that were either coated with an anticoagulant (158 IU of heparin, Becton Dickinson, Franklin Lakes, NJ) or were not (Becton Dickinson) for separation of plasma and serum, respectively. A competitive serine protease inhibitor (Aprotinin, Sigma-A1153, Millipore-Sigma, Oakville, ON, Canada) was added to blood at a rate of $5 \mu \mathrm{g} / \mathrm{mL}$ immediately after the blood was transferred to heparin-coated vials. Subsequently, these vials were centrifuged at $3,000 \times g$ at $4^{\circ} \mathrm{C}$ for $20 \mathrm{~min}$, whereas those intended for serum were allowed to clot for $3 \mathrm{~h}$ before centrifugation $\left(3,000 \times g\right.$ at $4^{\circ} \mathrm{C}$ for $\left.20 \mathrm{~min}\right)$. Supernatants were aliquoted $(1.5 \mathrm{~mL}$ per aliquot) into 3 microcentrifuge tubes, then stored at $-20^{\circ} \mathrm{C}$ until analysis of plasma GLP-2 and serum IGF-1.

Table 1. Diet nutrient composition and intake from 12 to $72 \mathrm{~h}$ for calves fed pooled and pasteurized colostrum (COL), a 1:1 mixture of colostrum:whole milk (MIX), or whole milk (WM) after an initial meal of colostrum

\begin{tabular}{lccccc}
\hline Item & COL & MIX & WM & SEM & $P$-value \\
\hline DM, \% & 23.0 & 18.1 & 13.2 & - & - \\
Nutrient composition, \% DM & & & & - & - \\
Fat & 20.0 & 29.7 & 39.4 & - & - \\
Protein & 57.0 & 39.8 & 22.7 & - & - \\
Lactose & 12.2 & 21.2 & 30.3 & - & - \\
Urea-N, mg/dL & 34.4 & 24.3 & 14.2 & - & - \\
Gross energy, Mcal/kg as fed & 1.25 & 1.03 & 0.81 & - & - \\
IGF-1, $\mu \mathrm{g} / \mathrm{L}$ & 360.9 & 180.5 & - & & \\
Intake, g/meal & & & & & - \\
DM & $485.2^{\mathrm{a}}$ & $373.3^{\mathrm{b}}$ & $294.9^{\mathrm{c}}$ & 16.6 & $<0.001$ \\
Fat & $97.0^{\mathrm{b}}$ & $101.1^{\mathrm{ab}}$ & $116.2^{\mathrm{a}}$ & 4.4 & 0.013 \\
Protein & $276.3^{\mathrm{a}}$ & $166.0^{\mathrm{b}}$ & $67.0^{\mathrm{c}}$ & 8.0 & $<0.001$ \\
Lactose & $59.1^{\mathrm{c}}$ & $70.1^{\mathrm{b}}$ & $89.4^{\mathrm{a}}$ & 3.0 & $<0.001$ \\
Urea-N, mg/meal & $695.7^{\mathrm{a}}$ & $484.2^{\mathrm{b}}$ & $308.9^{\mathrm{c}}$ & 22.0 & $<0.001$ \\
Gross energy intake, Mcal/meal & $2.65^{\mathrm{a}}$ & $2.12^{\mathrm{b}}$ & $1.80^{\mathrm{b}}$ & 0.1 & $<0.001$ \\
IGF-1, $\mu \mathrm{g} /$ meal & 729.9 & 359.7 & - & 24.0 & $<0.001$ \\
\hline
\end{tabular}

${ }^{a-c}$ Means within a row with different superscripts differ $(P<0.05)$. 


\section{Slaughter and Intestinal Tissue Collection}

Calves were killed by exsanguination $75 \mathrm{~h}$ postnatal after reaching a surgical plane of anesthesia by administration of euthanyl (30 mg of pentobarbital/ $\mathrm{kg}$ of $75 \mathrm{~h}$ BW; Euthanyl, Vetoquinol, Lavaltrie, QC, Canada) via jugular catheter. The dissection was performed once death was confirmed by the absence of a heartbeat.

All equipment used for the dissection was sterilized before use by autoclaving. The abdomen was opened from the sternum to the anus to access the digestive tract. Cable ties were used to occlude the esophagus and rectum from the body and excising incisions were performed cranially and caudally of these ties, respectively. The GIT was removed, placed on a sterile tray, and specific, predetermined sections of the small intestine were located for sample collection. Duodenal and proximal jejunal tissue were respectively collected 7.5 and $100 \mathrm{~cm}$ distal of the abomasal pyloric sphincter. Distal jejunal tissue was collected $30 \mathrm{~cm}$ proximal to the cranial mesenteric artery. Ileal tissue was taken 30 $\mathrm{cm}$ in advance of the ileo-cecal junction (Malmuthuge et al., 2015). Tissues were preserved in $15 \mathrm{~mL}$ of formalin and embedded within $48 \mathrm{~h}$ (described below) for histomorphometric analysis by brightfield microscopy.

\section{Brightfield Microscopy and Measurements}

Histomorphometric measurements of the duodenal, proximal and distal jejunal, and ileal villi and crypts were performed to detect differences in intestinal growth and developmental state (Wongdee et al., 2016). Small intestinal tissue was dehydrated overnight by a series of ethanol solution incubations. Once dehydrated, the samples were embedded and solidified in paraffin wax, sectioned ( $5 \mu \mathrm{m}$ slice per section, 2 sections per sample) using a rotary microtome (Leica, Wetzlar, Germany), and stained with hematoxylin and eosin. Slides were mounted using an upright brightfield microscope (Microscope Axio Scope.A1, Carl Zeiss Canada Ltd., Toronto, ON, Canada), whereas ImageJ software (ImageJ, National Institute of Health, Bethesda, MD) was used to quantify villi height and width and crypt depth and width $(\mu \mathrm{m})$ in the duodenum, proximal and distal jejunum, and ileum. An auto-generated grid was overlaid on each image for visual accuracy and consistency. Villi were measured from the fully attached epithelial cell to the villus-crypt junction. Crypts were measured from the villus-crypt junction to the tip of the crypt (Wongdee et al., 2016). Two measurements from 5 different images per slide (10 measurements/small intestinal region) were taken under $100 \times$ magnification. Widths were measured perpendicularly from the mid-section of 2 fully attached villi and crypts/image, resulting in 10 measurements/calf of villi and crypt width for duodenal, proximal and distal jejunal, and ileal regions. All measurements were averaged by calf and analyzed as one observation per dependent variable per experimental unit.

Villi height and crypt depth were used to determine the villi:crypt ratio and the mucosal surface area index was estimated from the mucosal-to-serosal amplification ratio (equation 1), originally presented in Kisielinski et al. (2002). The formula to estimate mucosal surface area index by the mucosal-to-serosal amplification ratio, using histomorphometric measures of villi and crypts is as follows:

$$
\mathrm{M}=\frac{\left[(\mathrm{a} \times \mathrm{b})+\left(\frac{\mathrm{a}}{2}+\frac{\mathrm{c}}{2}\right)^{2}-\left(\frac{\mathrm{a}}{2}\right)^{2}\right]}{\left(\frac{\mathrm{b}}{2}+\frac{\mathrm{c}}{2}\right)^{2}}
$$

where $\mathrm{M}=$ mucosal surface area index, $\mathrm{a}=$ villi width $(\mu \mathrm{m}), \mathrm{b}=$ villi height $(\mu \mathrm{m})$, and $\mathrm{c}=$ crypt width $(\mu \mathrm{m})$.

\section{Proliferating Cell Nuclear Antigen Quantification}

Proliferating cell nuclear antigen (PCNA) immunohistochemistry was used to quantify the proportion of proliferative cells (Hall et al., 1990) in the proximal jejunum and ileum. Samples were prepared from the same paraffin-embedded blocks of proximal jejunum and ileum as previously described. Blocks were cut in $5-\mu \mathrm{m}$ sections, which were rehydrated on a Leica CV 5030 autostainer program 2 (Leica). Antigen retrieval was performed with citrate for $16 \mathrm{~min}$ at $80 \%$, followed by cooling for $30 \mathrm{~min}$. The sections were then washed twice in PBS, followed by quenching for $6 \mathrm{~min}$ in a solution of $10 \mathrm{~mL}$ of $50 \% \mathrm{H}_{2} \mathrm{O}_{2}$ in $40 \mathrm{~mL}$ of $100 \%$ methanol. Sections were rinsed with distilled water for $5 \mathrm{~min}$ followed by 1-min rinse in PBS. Nonspecific adherence of antibodies was blocked with $20 \%$ normal goat serum (NGS) for 60 min. Normal goat serum was aspirated and the rabbit anti-PCNA antiserum was added for 60 min. The anti-PCNA antisera (Ab18197-Rabbit anti PCNA; Abcam Inc., Toronto, ON, Canada) was diluted 1:2,000 with $20 \%$ goat serum (NGS, Cedarlane, Burlington, ON, Canada). A biotinylated goat anti-rabbit antibody (Abcam, Cambridge, MA) was diluted 1:200 with NGS and applied as a secondary antibody for 40 min, then washed with PBS 3 times. Avidin-biotin complex (Cedarlane) was added for $40 \mathrm{~min}$, followed by PBS washing 3 times before 3,3'-diaminobenzidine (Cedarlane) solution was applied. When adequate color intensity was reached, sections were washed with dis- 
tilled water and counterstained with hematoxylin. Proliferating cell nuclear antigen samples were quantified using an upright brightfield microscope (Microscope Axio-Scope A.1, Carl Zeiss Canada Ltd.), whereby color intensity thresholds were manually set for individual sections with the ImageJ program (ImageJ, National Institutes of Health, Bethesda, MD). Five images of each slide were captured. The cells that were opaque and fully stained were considered to be $\mathrm{PCNA}^{+}$, proliferative cells. The proportion of $\mathrm{PCNA}^{+}$cells/total cells from 2 crypts were measured per image under $400 \times$ magnification (10 measurements per GIT region). Proliferative index measurements were averaged within GIT region by calf to represent one observation per dependent variable per experimental unit.

\section{Plasma GLP-2 and Serum IGF-1}

Plasma GLP-2 was measured using a solid-phase competition assay (Sugino et al., 2004; Inabu et al., 2018). Human GLP-2 labeled with Europium (Peptide Institute Inc., Osaka, Japan), polyclonal anti-rat GLP-2 serum, and goat-anti-rabbit- $\gamma$-globulin coated polystyrene microtiter strips (Yanaihara Institute Inc., Shizuoka, Japan) were used to target the N-terminal of GLP-2, as described by Inabu et al. (2017) and validated by Elsabagh et al. (2017). The intra- and interassay coefficients of variation were 6.5 and $10.6 \%$, respectively. Serum was frozen at $-20^{\circ} \mathrm{C}$ and shipped overnight on dry ice to the Endocrine Service Lab (Western College of Veterinary Medicine, University of Saskatchewan, Saskatoon, SK, Canada) for analysis of IGF-1 by an automated solid-phase chemiluminescent immunoassay using an Immulite 1000 Immunoassay System (Siemens AG, Munich, Germany). The Immulite/Immulite 1000 system was calibrated following the instructions provided by the manufacturer. The intra- and interassay coefficients of variation for the IGF-1 analysis were 5.0 and $4.1 \%$, respectively.

\section{Area Under the Curve Calculation}

Area under the curve (AUC) was calculated for GLP-2 (at 6-h intervals) and IGF-1 (by measurement interval) using an equation based on the trapezoidal rule and cumulated to represent $\mathrm{AUC}_{0-72}$ and $\mathrm{AUC}_{12-72}$. Following the first $(12 \mathrm{~h})$ and fifth $(60 \mathrm{~h})$ treatment meals, 2-, 4-, and 12-h AUC intervals were calculated for GLP-2.

\section{Statistical Analysis}

All statistical analyses were performed using SAS 9.4 (SAS Institute Inc., Cary, NC). PROC UNIVARIATE was used to analyze normality. Shapiro-Wilk $P>0.05$ was used to identify that residuals were normally distributed, and data were confirmed to be homoscedastic by visual appraisal of distribution plots. All data were found to be normally distributed.

Small intestinal histomorphometric measurements and PCNA analysis were assessed as a one-way ANOVA using PROC MIXED defining treatment as a fixed effect within the model (shown below). Tukey's post-hoc test was used to distinguish means that differed.

$$
\mathrm{Y}_{i j}=\mu+\text { treatment }_{i}+\varepsilon_{i j}
$$

$\mathrm{Y}_{i j}=$ the $j$ th observation in the $i$ th treatment, $\mu=$ the overall mean, treatment ${ }_{i}=$ the fixed effect of the $i$ th treatment, and $\varepsilon_{i j}=$ the random error associated with the $j$ th observation in the $i$ th treatment.

Measurements conducted over time (i.e., GLP-2 and IGF-1) additionally included the fixed effects of time and the treatment by time interaction:

$\mathrm{Y}_{i j k l}=\mu+$ treatment $_{i}+$ time $_{j}+(\operatorname{Trt} \times \mathrm{T})_{i j}+$ calf $_{k}+\varepsilon_{i j k l}$,

where $\mathrm{Y}_{i j k l}=$ the $l$ th observation of the $k$ th calf in the $i$ th treatment at the $j$ th time, $\mu=$ the overall mean, treatment $_{i}=$ the fixed effect of the $i$ th treatment, time $_{j}$ $=$ the fixed effect of the $j$ th time, calf $_{k}=$ the random effect of the $k$ th calf, $(\operatorname{Trt} \times \mathrm{T})_{i j}=$ the fixed effect of the interaction of the $i$ th treatment at the $j$ th time, $\varepsilon_{i j k l}$ $=$ the random error associated with the $l$ th observation of $k$ th calf in the $i$ th treatment at the $j$ th time.

Degrees of freedom were defined using the KenwardRoger approximation to account for unbalanced observations at specific time points. Covariance was modeled to clarify the auto-correlation between observations from one experimental unit repeated over time. Multiple covariances structures were tested and their appropriateness of fit to the model was determined (by the lowest Bayesian and Akaike information criterions) individually for dependent variables. Variance components, compound symmetry, unstructured, ante-dependence, and heterogeneous compound symmetry were tested as covariance structures with data that were unequally spaced, whereas equally spaced data were additionally tested with autoregressive, heterogeneous autoregressive, Toeplitz, and heterogeneous Toeplitz covariance structures. Outlier detection was performed after variance had been properly partitioned within the abovedescribed statistical model. Outliers were detected in both the GLP-2 and IGF-1 repeated measures by using PROC REG to regress the observation by the predicted response and generate the studentized residual and studentized-deleted residual. Only observations whose 
studentized-deleted residuals were $>3$ standards deviations from the predicted residual were removed from the data set. The IGF-1 measurement of one MIX calf at $12 \mathrm{~h}$ after birth was determined to be an outlier and was removed from the IGF-1 data set. All repeated measurements were corrected using the Bonferroni test. Means are considered different by $P<0.05$ and trends are discussed when $0.05 \leq P \leq 0.10$.

\section{RESULTS}

\section{Dry Matter, Nutrient, Gross Energy, and IGF-1 Intake}

When calves were fed treatment meals from 12 to $72 \mathrm{~h}$, COL-fed calves consumed 111.9 and $190.6 \pm$ $16.6 \mathrm{~g}$ of $\mathrm{DM} /$ meal more $(P<0.001)$ than MIX- and WM-fed calves. Milk-fed calves consumed $78.4 \pm 23.5$ g DM/d less than MIX-fed calves. Fat intake per meal was $19.8 \%$ greater $(P=0.013$; Table 1$)$ when calves were fed WM rather than COL, though neither COL nor WM fat intake differed from MIX. Colostrum-fed calves had increased protein $(1.64 \times \mathrm{MIX}, 4.12 \times \mathrm{WM}$; $P<0.001)$, urea $(1.44 \times \mathrm{MIX}, 2.25 \times \mathrm{WM} ; P<0.001)$, and gross energy $(\mathbf{G E})$ intake $(1.25 \times$ MIX, $1.47 \times$ WM; $P<0.001)$ but decreased lactose intake $(0.84$ $\times$ MIX, $0.66 \times \mathrm{WM} ; P<0.001)$ per meal than their counterparts. Protein and urea intake were respectively greater $(P<0.001)$ by $99.0 \pm 11.4 \mathrm{~g} /$ meal and 175.3 $\pm 31.2 \mathrm{mg} / \mathrm{meal}$ when calves were fed MIX instead of $\mathrm{WM}$, whereas lactose intake was $19.3 \pm 3.0 \mathrm{~g} /$ meal less $(P<0.001)$ for MIX- than WM-fed calves. Gross energy intake per meal did not differ between MIX (2.12 $\pm 0.13 \mathrm{Mcal} / \mathrm{meal})$ and WM $(1.80 \pm 0.13 \mathrm{Mcal} / \mathrm{meal})$.

When the contribution of the 2-h colostrum meal to total daily intake was considered, COL calves continued to consume 191.8 and $302.7 \pm 37.8 \mathrm{~g}$ of $\mathrm{DM} / \mathrm{d}$ more $(P$ $<0.001$; Table 2) than MIX and WM calves, respectively; however, MIX and WM calves did not differ in their daily DMI. Fat intake per day was increased $(P$ $=0.034$ ) by $16.6 \%$ for WM relative to COL, and MIX calves consumed similar quantities of fat as both WM and MIX. Colostrum protein intake remained elevated $(1.45 \times$ MIX, $2.32 \times \mathrm{WM} ; P<0.001)$, whereas lactose consumption was only less $(P<0.001)$ than WM-fed calves by $52.2 \pm 6.3 \mathrm{~g} / \mathrm{d}$. Feeding MIX rather than WM similarly resulted in calves consuming $1.60 \times$ more $(P$ $<0.001)$ protein and $0.19 \times$ less $(P<0.001)$ lactose per day. Again, daily urea consumption was greatest $(P$ $<0.001)$ when calves were fed COL as intake was 624.0 $\pm 51.2 \mathrm{mg} / \mathrm{d}$ lower for WM calves, with MIX calves consuming intermediary quantities of urea that were $360.2 \pm 51.2 \mathrm{mg} / \mathrm{d}$ less than COL but $263.8 \pm 51.2$ $\mathrm{mg} / \mathrm{d}$ more than WM. Daily GE intake was highest $(P<0.001)$ for COL $(5.73 \pm 0.21 \mathrm{Mcal} / \mathrm{d})$ compared with MIX $(4.83 \pm 0.21 \mathrm{Mcal} / \mathrm{d})$ and WM calves (4.40 $\pm 0.21 \mathrm{Mcal} / \mathrm{d})$. Between MIX and WM, GE intake per day was not different. By purposely lowering meal provision from 7.5 to $5 \% \mathrm{BW}$ at $12 \mathrm{~h}$, all calves had consistently reduced $(P<0.001) \mathrm{DM}(-31.4 \%)$, fat $(-16.9 \%)$, protein $(-42.4 \%)$, lactose $(-10.3 \%)$, urea $(-36.1 \%)$, and GE intake $(-29.5 \%)$ during d 2 and 3 compared with d 1. Dry matter, fat, protein, lactose, urea, and GE intakes were not different between d 2 and 3 . Numerous treatment $\times$ time interactions were present $(P<0.001)$ in DM, nutrient, and GE intake between treatments among days and are presented in Supplemental Figure S1 (https://doi.org/10.3168/jds .2019-17219) and described in Supplemental File S1 (https://doi.org/10.3168/jds.2019-17219).

Insulin-like growth factor-1 intake per meal for COL was twice that $(P<0.001)$ of the MIX calves and nonmeasurable for the WM calves. As such, WM IGF-1 intake could not be compared with that of COL and MIX. For the COL and MIX calves, IGF-1 intake was $1.5 \times$ greater $(P<0.001)$ on $\mathrm{d} 1$ than both $\mathrm{d} 2$ and 3 . A treatment by time interaction was detected $(P<0.001)$ for IGF-1 intake between COL and MIX calves and is presented in Supplemental Figure S2 (https://doi.org/ 10.3168/jds.2019-17219).

\section{Small Intestine Histomorphology and Proliferation Index}

Proximal jejunum histomorphology is visually (Figure 1; image A: COL; image B: MIX; image C: WM) distinguishable among treatments with the most development of villi and mucosa being discernable in COL and MIX images. Villi height was greater in the proximal $(P<0.001$; Table 3$)$ and distal $(P=0.008)$ jejunum by 79.7 and $52.1 \%$, respectively, when calves were fed COL compared with milk. Similarly, proximal and distal jejunum villi height were 84.5 and $53.1 \%$ increased and tended to be 49.1 and $35.1 \%$ greater in the duodenum $(P=0.067)$ and ileum $(P=0.098)$ for MIX relative to WM calves. These metrics did not differ between calves fed COL and MIX. Regardless of GIT region, crypt depth was not affected $(P \geq 0.26)$ by feeding COL, MIX, or WM to calves. The villi height: crypt depth ratio in the proximal jejunum was lessened $(P=0.003)$ for $\mathrm{WM}$ calves to 0.52 and 0.57 times than that of the COL and MIX calves, whereas the MIX duodenal villi:crypt ratio tended $(P=0.072)$ to be $53.3 \%$ greater than the WM. The ratio of villi height:crypt depth did not differ $(P \geq 0.12)$ by treatment in the distal jejunum or ileum. Colostrum and MIX calves had a greater mucosal surface area than WM calves in the proximal jejunum $(P=0.001)$ and ileum $(P=0.010)$; however, they did not differ from each other. Calves fed 
Pyo et al.: EXTENDED COLOSTRUM FEEDING

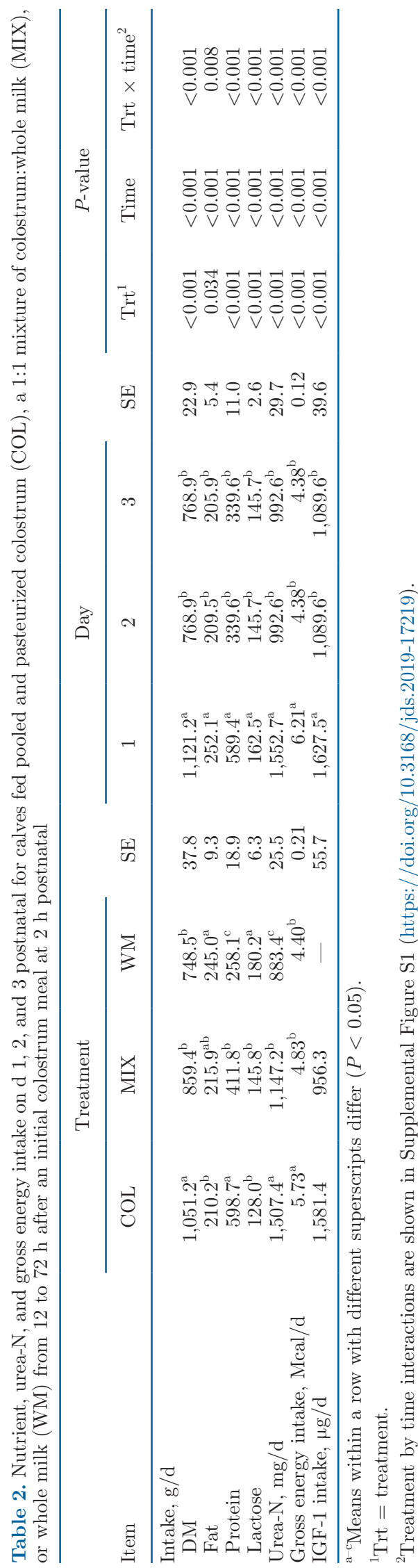

MIX had $1.54 \times$ greater $(P=0.001)$ surface area than WM in the distal jejunum, whereas COL surface area within this region was similar to both MIX and WM. Duodenal surface area index was unaffected $(P=0.27)$ by feeding COL, MIX, or WM from 12 to $72 \mathrm{~h}$.

Although treatment only tended $(P=0.054)$ to cause the proportion of $\mathrm{PCNA}^{+}$cells in the ileal crypts to increase by $5.2 \%$ units for MIX compared with WM calves, Tukey's post-hoc test indicated that these means were separate $(P=0.044$, MIX vs. WM). Calves consuming COL did not have a different $(P \geq 0.36)$ ileal crypt cell proliferative index than MIX or WM. The percentage of $\mathrm{PCNA}^{+}$crypt cells did not differ $(P$ $=0.34$ ) by treatment in the proximal jejunum.

\section{Plasma GLP-2 and Serum IGF-1}

Plasma GLP-2 concentration did not differ $(P \geq 0.85$; Table 4) between COL, MIX, and WM calves from 0 to $72 \mathrm{~h}$ or 12 to $72 \mathrm{~h}$. Similarly, the treatment by time interaction did not affect $(P \geq 0.69)$ GLP-2 concentrations during these time intervals. However, plasma GLP-2 concentration between 0 to $72 \mathrm{~h}$ and 12 to $72 \mathrm{~h}$ fluctuated $(P<0.001$; Figure 2$)$ over time. Regardless of considering either the 60 or $72 \mathrm{~h}$ timeline, GLP-2 was lower during d 2 at 27,30,36, and $42 \mathrm{~h}$ compared with the periods immediately following 12 and $60 \mathrm{~h}$, although by $48 \mathrm{~h}$ postnatal, plasma GLP-2 began to recover and was similar to concentrations during the high-frequency measurements (12-h periods) at 12 and $60 \mathrm{~h}$. At $27,30,36$, and $42 \mathrm{~h}$, GLP-2 was equivalent to the low values $(0.49 \pm 0.1 \mathrm{ng} / \mathrm{mL})$ observed immediately before the first meal after birth at $2 \mathrm{~h}$.

An interaction of treatment and time $(P=0.028)$ was present between 12 to $14 \mathrm{~h}$. Calves that were fed WM had GLP-2 concentrations that were $1.32 \times$ greater at $12.5 \mathrm{~h}$ than their own concentrations at 14 $\mathrm{h}$, but did not differ from COL or MIX at any time point in the $2 \mathrm{~h}$ postprandial. Otherwise, treatment did not affect $(P=0.58)$ GLP-2 concentrations from 12 to $14 \mathrm{~h}$, and similarly, treatment and treatment by time had no influence $(P \geq 0.57)$ on GLP-2 from 12 to 16 $\mathrm{h}$ or 12 to $24 \mathrm{~h}$. Time affected $(P=0.022)$ GLP-2 concentrations between 12 to $14 \mathrm{~h}$, but means were not separate after post-hoc adjustment. Plasma GLP-2 concentrations changed $(P<0.001)$ between 12 and 24 $\mathrm{h}$, but changes were marginal and reflected increased GLP-2 concentrations at $12.5 \mathrm{~h}$ compared with $24 \mathrm{~h}$.

For $2 \mathrm{~h}$ postprandial of $60 \mathrm{~h}$, COL calves GLP-2 was $59.4 \%$ greater $(P=0.012)$ than WM. During this timeframe, MIX-fed calves GLP-2 concentration was equivalent to both COL and WM. Glucagon-like peptide-2 tended ( $P=0.052)$ to remain elevated ( $46.4 \%$ greater) from 60 to $64 \mathrm{~h}$ for COL calves compared with WM 


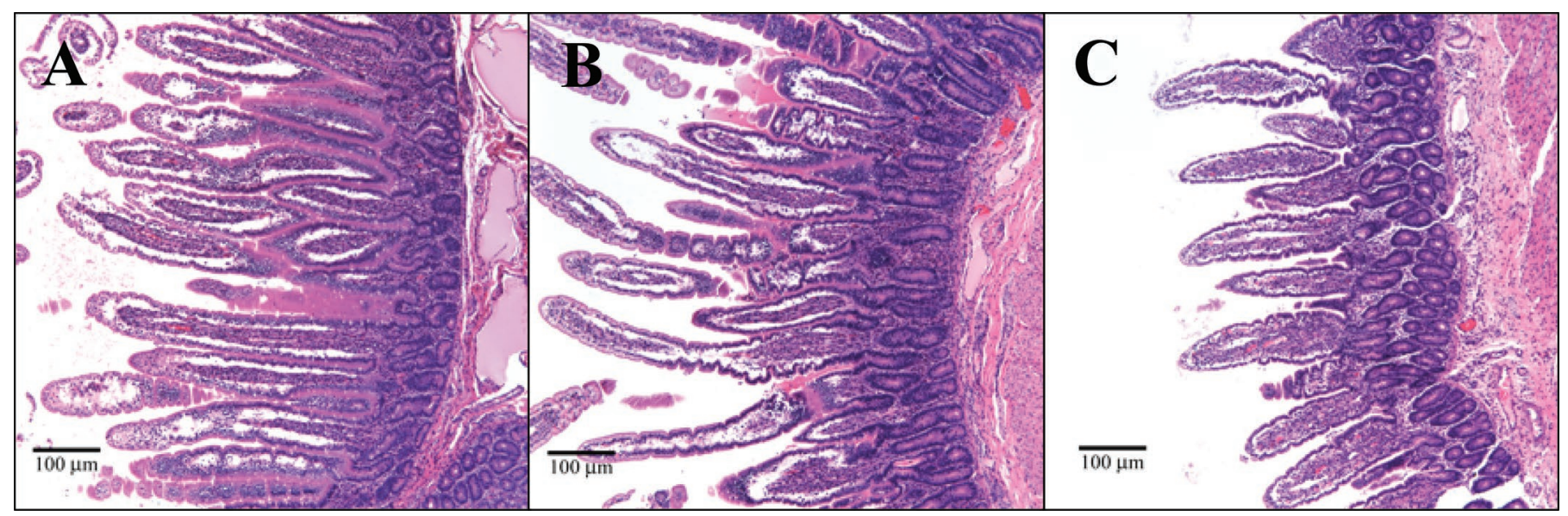

Figure 1. Brightfield microscopy images (200× magnification) of proximal jejunal tissue from calves that consumed either pooled and pasteurized colostrum (A), a 1:1 colostrum:whole milk mixture (B), or whole milk (C) from 12 to $72 \mathrm{~h}$ after an initial meal of colostrum at $2 \mathrm{~h}$ postnatal. Jejunal tissue is stained with hematoxylin and eosin for contrast.

calves. From 60 to $72 \mathrm{~h}$, treatment differences were no longer present $(P=0.17)$. Additionally, no treatment by time interactions $(P \geq 0.30)$ were detected from 60 to $62 \mathrm{~h}, 60$ to $64 \mathrm{~h}$, or 60 to $72 \mathrm{~h}$. Time-dependent response patterns in GLP-2 were detected from 60 to $62 \mathrm{~h}(P=0.034), 60$ to $64 \mathrm{~h}(P=0.041)$, and 60 to $72 \mathrm{~h}(P=0.011)$, but means did not separate after Bonferroni adjustment.

Glucagon-like peptide-2 AUC did not change throughout the entire experimental period $(P \geq 0.41$; Table 5) or in the 2-, 4-, and 12-h intervals at 12 and 60 h $(P \geq 0.22$; Supplemental Table S1; https://doi.org/ $10.3168 /$ jds.2019-17219) by the effect of treatment, time, or the interaction of treatment and time. The treatment $\times$ time effect $(P \leq 0.048)$ on GLP- $2_{12 \mathrm{~h}}$ AUC after 12 and $60 \mathrm{~h}$ was not different once corrected for multiple comparisons.

Neither treatment nor the interaction of treatment and time affected $(P \geq 0.14$; Table 4$)$ serum IGF-1 from 1 to $72 \mathrm{~h}$ or 12 to $72 \mathrm{~h}$. Serum IGF-1 concentration was elevated $(P<0.001$; Figure 3$)$ for the first 24 $\mathrm{h}$ postnatal, peaking at $18 \mathrm{~h}(83.8 \pm 3.4 \mathrm{ng} / \mathrm{mL})$ and thereafter declining by $9.9,74.9,98.7$, and $75.1 \%$ relative to $24,36,48$, and $72 \mathrm{~h}$ postnatal. Concentration of IGF-1 at $72 \mathrm{~h}$ was $28.4 \mathrm{ng} / \mathrm{mL}$ less than concentrations at $24 \mathrm{~h}$ yet remained unchanged relative to 36 and 48 h. The same time-dependent changes $(P<0.001$; data not shown) in IGF-1 concentration were observed when evaluating only the interval that calves were fed their respective treatments (12 to $72 \mathrm{~h}$ ). Yet, IGF-1 AUC from 12 to $72 \mathrm{~h}$ tended to be greater $(P=0.088$; Table 5) for COL than WM calves (3,771.04 vs. 2,973.17 \pm $248.7 \mathrm{ng} / \mathrm{mL} \times \mathrm{h}$ ), whereas MIX did not differ from either. This difference was not present in the 1 to $72 \mathrm{~h}$ serum IGF-1 AUC.

\section{DISCUSSION}

The current study aimed to compare the maturation of the neonatal calf GIT and relevant endocrine signals to GIT development (i.e., GLP-2 and IGF-1) when the natural transition in postnatal macronutrient and bioactive compound ingestion was mimicked. Though the composition of transition milk gradually shifts to that of mature milk by 3 to $4 \mathrm{~d}$ postpartum (Blum and Hammon, 2000), in the current study transition milk was simulated in the MIX treatment by combining and feeding equal parts COL and WM. Providing a fixed nutrient intake for the MIX treatment was necessary to remove the confounding influence of inconsistent daily nutrient or bioactive factor intake on measurements performed over time (i.e., plasma GLP-2 and serum IGF-1 concentrations). In addition, the MIX macronutrient composition $(29.7 \%$ crude fat, $39.8 \%$ CP, $21.2 \%$ lactose, \% DM) is similar to the reported transition milk compositions (milkings 2 to 6; Blum and Hammon, 2000) that correspond to the 72-h experiment duration. Thus, the MIX treatment adequately simulated transition milk and the experimental model was appropriate to study neonatal physiological responses to colostrum, transition milk, or whole milk provision.

Histomorphology has been used as a proxy to indicate development and functional capacity of the small intestine and evidence very clearly shows that consumption of milk or milk replacer instead of colostrum impedes the capacity of the neonatal GIT to achieve its developmental potential (Bühler et al., 1998; Steinhoff-Wagner et al., 2014; Yang et al., 2015). It is not unexpected that reductions in villi height, villi height:crypt depth ratio in the duodenum and proximal jejunum, and mucosal surface area in the proximal and distal jejunum and il- 
Table 3. Histomorphometric measurements of villi and crypts within the duodenum, proximal and distal jejunum, and ileum and the proportion of proliferative cell nuclear antigen positive $\left(\mathrm{PCNA}^{+}\right)$crypt cells in the proximal jejunum and ileum of neonatal Holstein bull calves fed either pooled and pasteurized colostrum (COL), a 1:1 mixture of colostrum:whole milk (MIX), or whole milk (WM) from 12 to $72 \mathrm{~h}$ after an initial meal of colostrum at $2 \mathrm{~h}$ postnatal

\begin{tabular}{|c|c|c|c|c|c|}
\hline \multirow[b]{2}{*}{ Variable } & \multicolumn{3}{|c|}{ Treatment } & \multirow{2}{*}{$\begin{array}{c}\text { Pooled } \\
\text { SEM }\end{array}$} & \multirow[b]{2}{*}{$P$-value } \\
\hline & COL & MIX & WM & & \\
\hline \multicolumn{6}{|l|}{ Villi height, ${ }^{1} \mu \mathrm{m}$} \\
\hline Duodenum & $395.0^{\mathrm{AB}}$ & $440.8^{\mathrm{B}}$ & $295.6^{\mathrm{A}}$ & 41.5 & 0.067 \\
\hline Proximal jejunum & $468.3^{\mathrm{a}}$ & $480.7^{\mathrm{a}}$ & $260.6^{\mathrm{b}}$ & 31.3 & $<0.001$ \\
\hline Distal jejunum & $463.3^{\mathrm{a}}$ & $466.4^{\mathrm{a}}$ & $304.6^{\mathrm{b}}$ & 37.4 & 0.008 \\
\hline Ileum & $428.8^{\mathrm{AB}}$ & $453.7^{\mathrm{B}}$ & $335.8^{\mathrm{A}}$ & 39.4 & 0.098 \\
\hline \multicolumn{6}{|l|}{ Crypt depth, ${ }^{2} \mu \mathrm{m}$} \\
\hline Duodenum & 189.1 & 201.0 & 211.2 & 18.3 & 0.71 \\
\hline Proximal jejunum & 195.5 & 211.4 & 202.7 & 14.1 & 0.73 \\
\hline Distal jejunum & 194.3 & 203.5 & 177.5 & 11.0 & 0.26 \\
\hline Ileum & 195.9 & 178.6 & 191.3 & 13.5 & 0.65 \\
\hline \multicolumn{6}{|c|}{ Villi height:crypt depth${ }^{3}$} \\
\hline Duodenum & $2.1^{\mathrm{AB}}$ & $2.3^{\mathrm{B}}$ & $1.5^{\mathrm{A}}$ & 0.2 & 0.072 \\
\hline Proximal jejunum & $2.5^{\mathrm{a}}$ & $2.3^{\mathrm{a}}$ & $1.3^{\mathrm{b}}$ & 0.2 & 0.003 \\
\hline Distal jejunum & 2.5 & 2.4 & 1.8 & 0.3 & 0.14 \\
\hline Ileum & 2.2 & 2.7 & 1.8 & 0.3 & 0.12 \\
\hline \multicolumn{6}{|c|}{ Mucosal surface area index } \\
\hline Duodenum & 6.5 & 6.9 & 5.0 & 0.8 & 0.27 \\
\hline Proximal jejunum & $8.0^{\mathrm{a}}$ & $7.9^{\mathrm{a}}$ & $5.0^{\mathrm{b}}$ & 0.5 & 0.001 \\
\hline Distal jejunum & $7.5^{\mathrm{ab}}$ & $9.1^{\mathrm{a}}$ & $5.9^{\mathrm{b}}$ & 0.5 & 0.001 \\
\hline Ileum & $8.3^{\mathrm{a}}$ & $9.1^{\mathrm{a}}$ & $6.0^{\mathrm{b}}$ & 0.7 & 0.010 \\
\hline \multicolumn{6}{|c|}{$\mathrm{PCNA}^{+}$crypt cells/total cells } \\
\hline Proximal jejunum & 0.35 & 0.36 & 0.33 & 0.01 & 0.34 \\
\hline Ileum $^{6}$ & $0.41^{\mathrm{ab}}$ & $0.43^{\mathrm{a}}$ & $0.38^{\mathrm{b}}$ & 0.01 & 0.054 \\
\hline
\end{tabular}

${ }^{\mathrm{a}, \mathrm{b}}$ Means within a row with different lowercase superscripts differ $(P<0.05)$.

${ }^{\mathrm{A}, \mathrm{B}}$ Means within a row with different uppercase superscripts tend to differ $(0.05 \leq P<0.10)$.

${ }^{1}$ Villi height (n) by gastrointestinal tract (GIT) region and treatment (COL, MIX, and WM, respectively) as follows: duodenum, $\mathrm{n}=8,8$, and 7 ; proximal jejunum, $\mathrm{n}=8,8$, and 8 ; distal jejunum, $\mathrm{n}=7$, 8 , and 8 ; and ileum, $\mathrm{n}=7,8$, and 8 .

${ }^{2}$ Crypt depth (n) by GIT region and treatment (COL, MIX, and WM, respectively) as follows: duodenum, $\mathrm{n}$ $=8,8$, and 6 ; proximal jejunum, $\mathrm{n}=8,8$, and 8 ; distal jejunum, $\mathrm{n}=8,8$, and 8 ; and ileum, $\mathrm{n}=7,8$, and 8 . ${ }^{3}$ Villi height:crypt depth ratio (n) by GIT region and treatment (COL, MIX, and WM, respectively) as follows: duodenum, $\mathrm{n}=8,8$, and 6 ; proximal jejunum, $\mathrm{n}=8,8$, and 8 ; distal jejunum, $\mathrm{n}=7,8$, and 8 ; and ileum, $\mathrm{n}$ $=7,8$, and 8 .

${ }^{4}$ Surface area (n) by GIT region and treatment (COL, MIX, and WM, respectively) as follows: duodenum, $\mathrm{n}$ $=7,8$, and 8; proximal jejunum, $\mathrm{n}=8,7$, and 8; distal jejunum, $\mathrm{n}=7,8$, and 8 ; and ileum, $\mathrm{n}=7,8$, and 8 .

${ }^{5}$ Surface area calculated according to the equation described by Kisielinski et al. (2002).

${ }^{6}$ Tukey's post-hoc test separated means despite the overall $P$-value being nonsignificant $(P>0.05)$.

eum were observed in WM calves when compared COL and MIX calves. However, that WM feeding tended to lessen the population of $\mathrm{PCNA}^{+}$crypt ileal cells is surprising since it was only relative to MIX, and not COL calves. Blättler et al. (2001) similarly found proliferative indices were greater in calves consuming transition milk (milkings 1 to 6 ; d 1 to 3 ) instead of a milk-based formula of similar macronutrient composition (d 1 to 3) before all calves being fed milk replacer from d 4 to 7. Their results differ from those of the current study, as proliferation of duodenal epithelia was also lower when calves consumed only first-milking colostrum (as opposed to transition milk; Blättler et al., 2001) for the first $3 \mathrm{~d}$ postnatal, indicating that extensive colostrum consumption could adversely affect small intestinal development relative to transition milk. Unfortunately, small intestinal proliferation of colostrum- relative to formula-fed calves was not reported by Blättler et al. (2001) and their results cannot be further compared with our own. However, Steinhoff-Wagner et al. (2014) found that calves that consumed colostrum as opposed to a colostrum-based formula had lessened crypt depth but greater villi circumference, area, and height than their counterparts (Steinhoff-Wagner et al., 2014), aptly coinciding with the results of the current study. Both Blättler et al. (2001) and Steinhoff-Wagner et al. (2014) proposed that the effect of extended colostrum feeding on intestinal crypt formation was positive and demonstrated furthered maturation, or potentially resulting from greater intestinal mass (Blättler et al., 2001). Increased migration of crypt epithelial cells to villi, reductions in apoptosis, and enhanced rates of 
crypt fission have been suggested as potential mechanisms for the decreased crypt proliferative rates and reduced depths (as reviewed by Blum, 2006) but it is still unclear which mechanism predominates.

It was hypothesized that GIT maturation would be promoted foremost by COL compared with MIX (intermediary) and WM. Colostrum and MIX feeding did indeed further GIT development to a greater extent than WM. Yet, extensive colostrum feeding did not provide an advantage compared with MIX feeding, as evidenced by the equivalent villi height and increased mucosal surface area between COL and MIX calves. Thus, the hypothesis was partially rejected as COL feeding did not provide additional benefit to small intestine maturation compared with MIX. These results are in contrast to previous research. Overall improved gut development has been reported in 8-d-old calves that had consumed colostrum as opposed to pooled transition milk on d 1 and 2 postnatal (Yang et al., 2015), whereas feeding first-milk colostrum until d 3 postnatal (rather than colostral milkings 1 to 6) only increased duodenal development in neonatal calves despite the colostrum-calves consuming a serially diluted colostrum from d 4 to 7 (Blättler et al., 2001). The latter study is more pertinent to the present than that of Yang et al. (2015) by the fact that calves were provided a primary colostrum feeding. Bühler et al. (1998) similarly fed an initial meal of colostrum to calves that then received milk replacer until euthanasia at $\mathrm{d} 8$ postnatal and contrasted these results to calves that were fed 6 colostrum meals before receiving milk replacer until $d$
8 postnatal. A lack of transition milk or a transition milk-mimic provision after the initial colostrum meal stunted intestinal development compared with calves that had received colostrum for $3 \mathrm{~d}$ (Bühler et al., 1998), coinciding with observations from the current study whereby COL small intestinal development was enhanced compared with WM regardless of WM calves consuming a primary meal of colostrum.

Based on the preceding discussions, it is possible that one timely feeding of colostrum may compensate to preserve and promote the functionality of the neonatal gut once consumption of transition milk begins. This is likely mediated in part by colostral bioactive compounds, yet the greater nutrient density of COL and MIX must be considered. Increased nutrient intake, and thus, availability of anabolic substrates for both COL and MIX calves on d 1 postnatal, likely supported the enhanced GIT development. This notion highlights the importance and potency of colostral bioactive compounds when they are consumed early in life, because MIX small intestine growth was preserved despite MIX calves having decreased nutrient and GE intake on d 2 and 3 postnatal compared with COL calves. However, the suggestion that a single colostrum feeding is sufficient to benefit calf development is currently limited solely to the GIT and likely only relevant when transition milk, not milk or milk replacer, is fed afterward. Still, this proposition has important practical implications for the dairy industry as preweaning morbidity (34\%; Urie et al., 2018) and mortality (6.4\%; Winder et al., 2018) is primarily caused by gastroin-

Table 4. Plasma glucagon-like peptide-2 (GLP-2) and serum IGF-1 concentrations in Holstein bull calves that were fed either pooled and pasteurized colostrum (COL), a 1:1 colostrum:whole milk mixture (MIX), or whole milk (WM) from 12 to $72 \mathrm{~h}$ after an initial meal of colostrum at $2 \mathrm{~h}$ postnatal

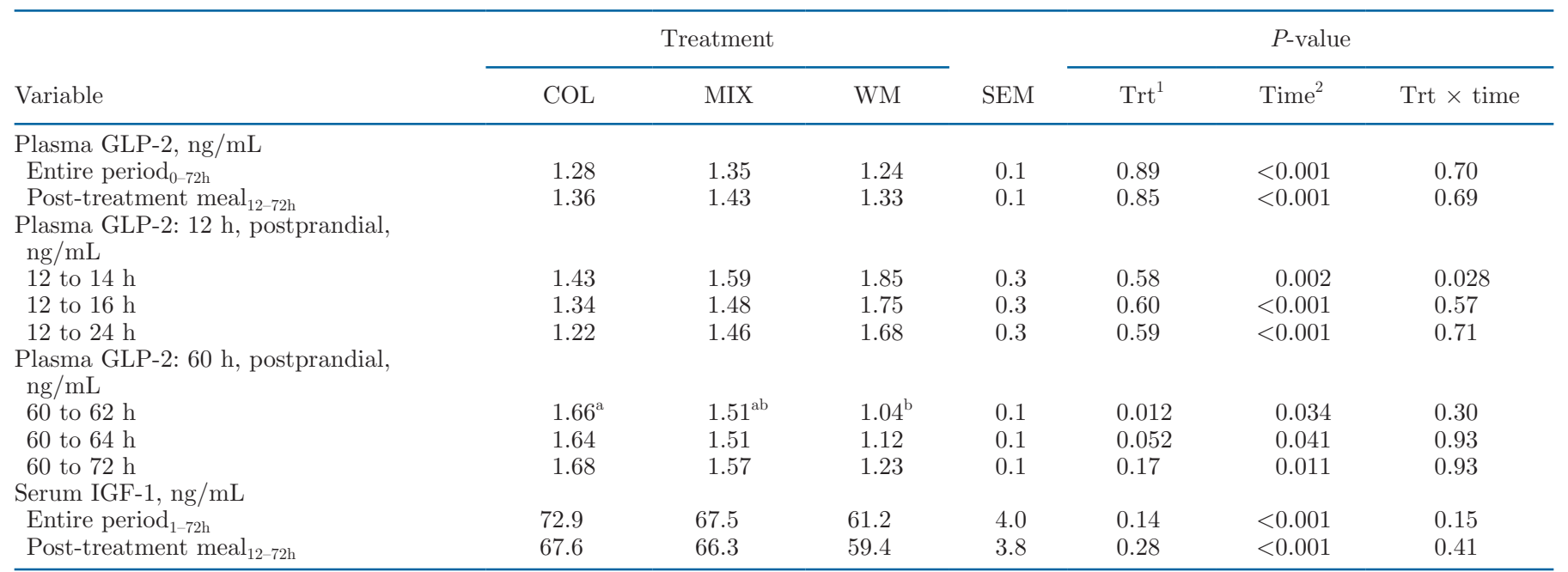

${ }^{\mathrm{a}, \mathrm{b}}$ Means with different superscripts differ $(P<0.05)$.

${ }^{1}$ Trt $=$ treatment

${ }^{2}$ The effect of time is expressed as hours postnatal. GLP-2 time effects are shown in Figure 2; and IGF-1 time effects are shown in Figure 3. 
Table 5. Total area under the curve (AUC) of glucagon-like peptide-2 (GLP-2) and IGF-1 over the entire experiment period $(0$ to $72 \mathrm{~h}$ ) and after the first treatment meal (12 to $72 \mathrm{~h}$ ) for Holstein bull calves fed pooled and pasteurized colostrum (COL), a 1:1 colostrum:whole milk mixture (MIX), or whole milk (WM) from $12 \mathrm{~h}$ onward after an initial meal of colostrum at $2 \mathrm{~h}$ postnatal

\begin{tabular}{lcccrc}
\hline & \multicolumn{3}{c}{ Treatment } & & P-value \\
\cline { 2 - 4 } Item & COL & MIX & WM & SEM & Treatment \\
\hline GLP-2 AUC, ${ }^{1} \mathrm{ng} / \mathrm{mL} \times \mathrm{h}$ & 88.2 & 87.0 & 80.8 & 9.3 & 0.83 \\
AUC $_{0-72 \mathrm{~h}}$ & 77.4 & 73.7 & 62.7 & 7.9 & 0.41 \\
AUC $_{12-72 \mathrm{~h}}$ & & & & \\
IGF-1 AUC, $^{1} \mathrm{ng} / \mathrm{mL} \times \mathrm{h}$ & $4,658.7$ & $4,444.4$ & $3,860.4$ & 294.6 & 0.16 \\
AUC $_{1-72 \mathrm{~h}}$ & $3,771.0^{\mathrm{A}}$ & $3,613.5^{\mathrm{AB}}$ & $2,973.2^{\mathrm{B}}$ & 248.7 & 0.088 \\
AUC $_{12-72 \mathrm{~h}}$ & &
\end{tabular}

$\overline{\mathrm{A}, \mathrm{B}}$ Means within a row with different superscripts tend to differ $(0.05 \leq P<0.10)$.

${ }^{1} \mathrm{AUC}$ is calculated by the formula $[(\mathrm{a}+\mathrm{b}) \times \mathrm{c}] / 2$; $\mathrm{a}=$ GLP-2 or IGF-1 concentration, $\mathrm{b}=$ GLP-2 or IGF-1 concentration, $\mathrm{c}=$ duration of time between measurements.

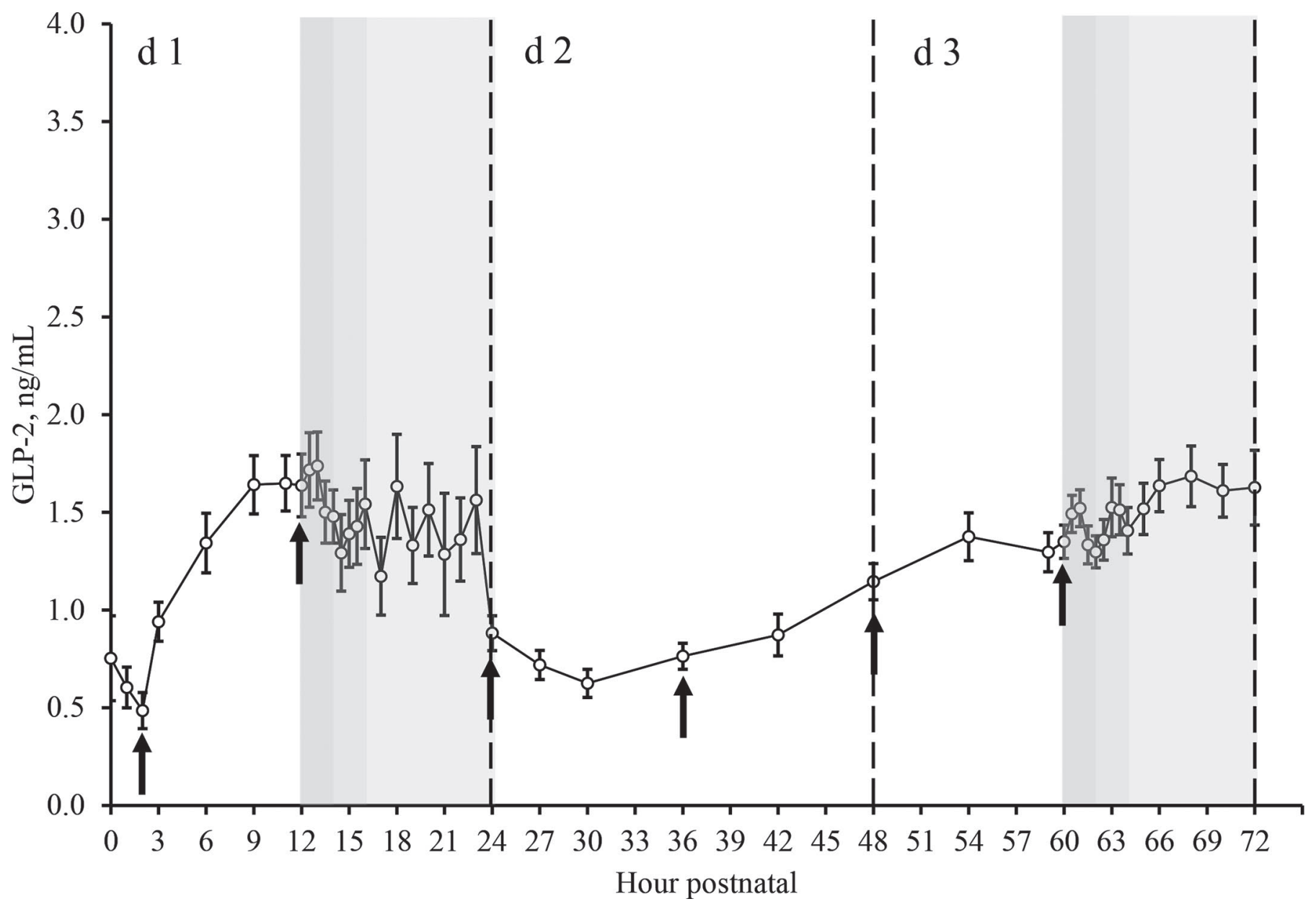

Figure 2. Plasma glucagon-like peptide-2 (GLP-2) concentrations of neonatal Holstein bull calves from 0 to $72 \mathrm{~h}$ and 12 to $72 \mathrm{~h}$ postnatal. Calves were offered treatments of pooled and pasteurized colostrum, a 1:1 mixture of colostrum:whole milk, or whole milk from 12 to $72 \mathrm{~h}$ after birth after all calves received an initial colostrum meal at $2 \mathrm{~h}$ postnatal. Black arrows represent when meals were fed, and shaded timeframes ( 12 to $14 \mathrm{~h}, 12$ to $16 \mathrm{~h}$, and 12 to $24 \mathrm{~h} ; 60$ to $62 \mathrm{~h}, 60$ to $64 \mathrm{~h}$, and 60 to $72 \mathrm{~h}$ ) demonstrate periods of frequent measurements that underwent additional statistical analysis relative to 12 - and 60-h meals. Plasma GLP-2 from 0 to $72 \mathrm{~h}$ and 12 to $72 \mathrm{~h}$ varied $(P<0.001)$ over time, such that GLP-2 concentrations were depressed from 27 to $42 \mathrm{~h}$ compared with their post-12 h concentrations, but began to recover by $42 \mathrm{~h}$ and were fully recovered by $48 \mathrm{~h}$ postnatal. Treatment and the treatment $\times$ time interaction did not affect $(P \geq 0.69)$ plasma GLP-2 from either 0 to 72 h or 12 to $72 \mathrm{~h}$ after birth. Error bars represent SE. 


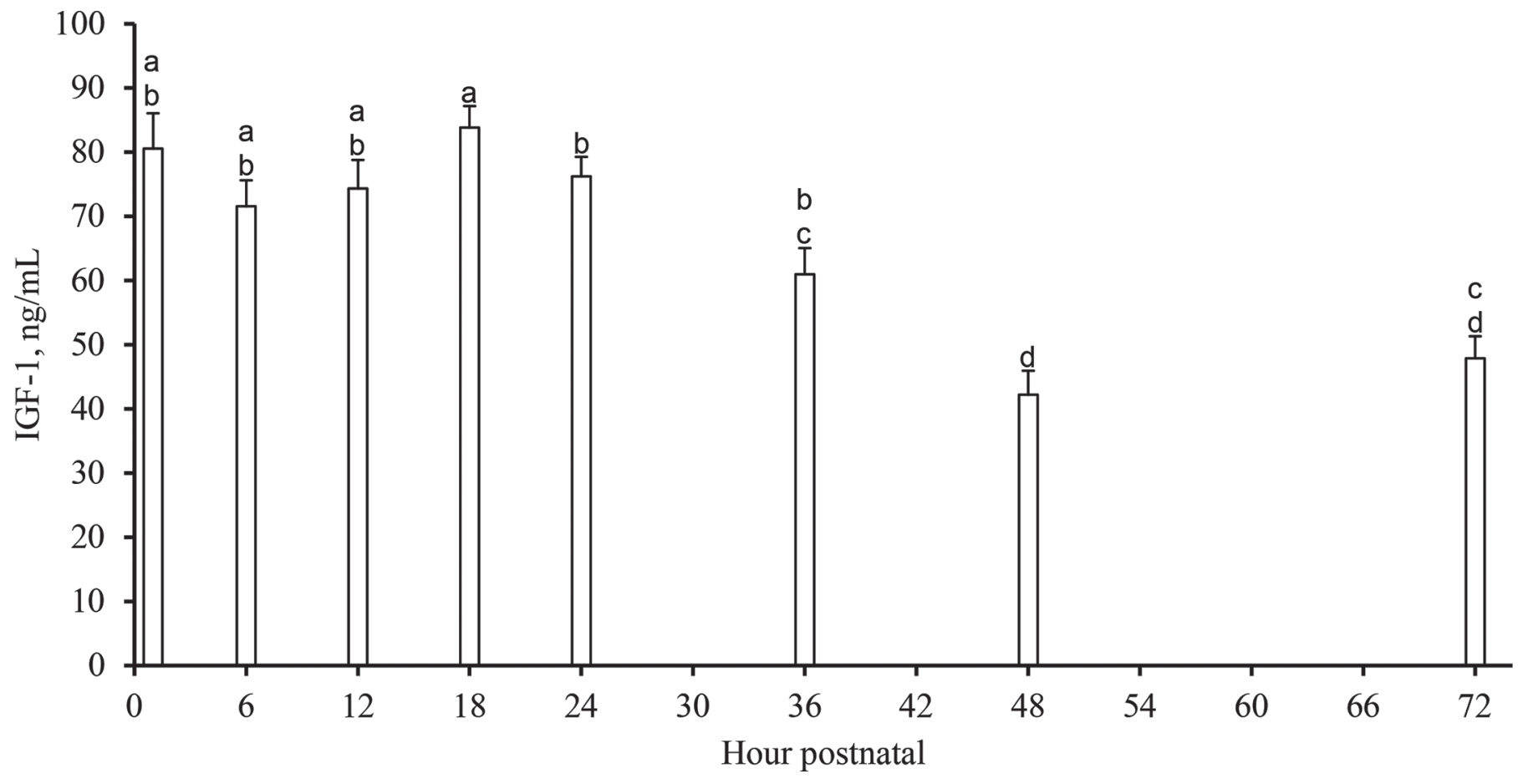

Figure 3. The change in serum IGF-1 over time for Holstein bull calves from 1 to $72 \mathrm{~h}$ postnatal. Calves were offered treatments of pooled and pasteurized colostrum, a 1:1 mixture of colostrum:whole milk, or whole milk from 12 to $72 \mathrm{~h}$ postnatal after all calves received an initial colostrum meal at $2 \mathrm{~h}$ postnatal. Time affected $(P<0.001)$ serum IGF-1 concentration as it was elevated from 1 to $18 \mathrm{~h}$, declined afterward, and was lowest at 48 and $72 \mathrm{~h}$ postnatal. Neither treatment $(P=0.14)$ nor the interaction of treatment and time $(P=0.15)$ influenced serum IGF-1 concentrations. Means with different letters differ $(P<0.05)$. Error bars represent SE.

testinal disorders (56 and 32\%, respectively; Urie et al., 2018). Promoting gastrointestinal development by feeding transition milk following colostrum provision could be a viable strategy for producers to decrease the incidence of preweaning digestive-associated morbidity. Further research is needed to determine how transition milk feeding, as compared with colostrum, whole milk, or milk replacer feeding, affects the incidence of digestive morbidity and preweaning mortality.

It is indisputable that colostrum is meant to further neonatal GIT ontogenesis (Guilloteau et al., 1997; Blum and Baumrucker, 2002; Zabielski et al., 2008; Ontsouka et al., 2016), as evidenced by its extensive nonnutritive bioactive factor content (reviewed by Blum and Hammon, 2000; McGrath et al., 2016) and capacity to stimulate the release of endogenous endocrine factors by nutrient delivery to the small intestine (Hadorn et al., 1997; Hammon et al., 2000; Inabu et al., 2018). Of particular interest to the current study is the oral delivery of IGF-1 in colostrum (Pakkanen and Aalto, 1997; Blum and Hammon, 2000) to the neonatal calf by its small intestine-targeted mitogenic capacity to increase epithelial cell proliferation (MacDonald, 1999; Shen et al., 2004). Because the mitogenic action of IGF-1 can be enhanced by GLP-2 (Dubé et al., 2006; Rowland et al., 2011; Leen et al., 2011), these 2 hormones were promising targets to determine their relationship to neonatal intestinal development and postnatal nutrient consumption.

Yet, study findings did not support the hypothesis that elevated plasma GLP-2 and serum IGF-1 concentrations would reflect and coincide with enhanced intestinal development by COL compared with MIX or WM feeding. These results are surprising because plasma GLP-2 is strongly correlated with nutrient intake and intestinal development in piglets (Burrin et al., 2000; Stoll et al., 2000) and mature humans (Holst et al., 1976; Xiao et al., 1999) and serum IGF-1 is positively influenced by adequate colostrum consumption (Hammon and Blum, 1997; Egli and Blum, 1998; Hammon et al., 2000). The previously discussed lack of difference in COL and MIX intestinal histomorphology could be related to the similar GLP-2 and IGF-1 concentrations for both groups. However, IGF-1 was also similar in WM-fed calves, despite these calves having hindered villi and surface area growth relative to their counterparts. The tendency for greater IGF-1 AUC from COL compared with WM consumption insufficiently relates to improved GIT development, particularly as calves consuming colostrum have been consistently demonstrated to have elevated serum IGF-1 and better small intestinal maturation than their counterparts (Hadorn 
et al., 1997; Hammon and Blum, 1997; Rauprich et al., 2000; Schäff et al., 2014). The tendency for increased IGF-1 AUC more likely relates to greater total nutrient and GE intake (Hammon et al., 2002; Inabu et al., 2019) when COL (compared with WM) was fed for an extended period of time (discussed below), particularly since negligible quantities of ingested IGF-1 cross the neonatal GIT in calves (Baumrucker and Blum, 1994; Vacher et al., 1995; Hammon and Blum, 1997) or pigs (Burrin, 1997; Donovan et al., 1997). The comparatively greater post-60 h plasma GLP-2 concentrations for COL rather than WM calves can also be considered minimal given that increases were only observed for up to $4 \mathrm{~h}$ after feeding and were not different between MIX and WM calves. To counterpoint, Burrin et al. (2003b) suggested circulating physiological GLP-2 concentrations may not accurately represent luminal GLP-2 concentrations and activity. This concept can be applied to our own results and may be one explanation for the apparent lack of plasma GLP-2 response to treatment provision or intestinal development. Yet, we cannot prove that GLP-2 was differentially secreted intra-luminally. Ultimately, plasma GLP-2 and serum IGF-1 did not correlate to improved small intestinal development within this study.

Calf IGF-1 concentrations are comparably lesser at birth than in later life (Greenwood et al., 2002; Quigley et al., 2006) but still decrease in the neonatal period when nutrient intake is restricted (Hadorn et al., 1997; Hammon and Blum, 1997; Hammon et al., 2000). This is a response that is consistent across species (Thissen et al., 1994; Greenwood et al., 2002) regardless of maturity (Ronge and Blum, 1988; Smith et al., 2002; Brown et al., 2005). In the current study, the maximum observed IGF-1 concentration $(83.8 \pm 3.4 \mathrm{ng} / \mathrm{mL}, 18$ $\mathrm{h}$ postnatal) was far lower than prior reported ranges of approximately 140 to $200 \mathrm{ng} / \mathrm{mL}$ during the first 24 h postnatal (Hadorn et al., 1997; Hammon and Blum, 1997). In fact, observed circulating IGF-1 concentrations in the current study are more similar to concentrations observed in calves that are purposefully nutrientrestricted (Hadorn et al., 1997; Hammon and Blum, 1997). Total nutrient and GE provision were greatest during the first $24 \mathrm{~h}$ postnatal by the combined feeding of colostrum and the first treatment meal. Afterward, total nutrient delivery (regardless of treatment) was reduced during d 2 and 3 compared with 1 . The initial decline in serum IGF-1 was observed at $24 \mathrm{~h}$ postnatal, corresponding to the second treatment meal provision and comparably (to meal 1) less nutrient and GE consumption. Nutrient intake is the initial regulator of the somatotropic growth axis (Breier and Gluckman, 1991; McGuire et al., 1995) and insufficient nutrient intake depresses circulating IGF-1 (Thissen et al., 1994;
Greenwood et al., 2002). As calves were not provided nutrients throughout the study at quantities equivalent to their allocation during $d 1$, it is not surprising that serum IGF-1 concentrations did not recover during the remainder of the study. It is possible that calves within the current study did not consume adequate nutrients to meet their requirements.

Glucagon-like peptide-2 is similarly reduced when nutrient intake is inadequate. A minimal enteral energy consumption of 40 to $60 \%$ is necessary to stimulate a GLP-2 response in 16-d-old piglets when compared with those fed $100 \%$ of their daily energy aliquot parenterally (Burrin et al., 2000) and, in 10- to 13-d old calves, reducing the milk replacer feeding rate to 1.31 ( $75 \%$ of control), 0.88 (50\% of control), and $0.44(25 \%$ of control) from $1.75 \% \mathrm{BW}$ as DM (control) caused corresponding decreases in circulating GLP-2 of 13 , 28 , and $51 \%$ compared with the control (Castro et al., 2016). Calf GLP-2 concentration in the present study was depressed during $\mathrm{d} 2$ by 44.3 and $46.5 \%$ relative to $\mathrm{d} 1$ (2 h post-colostrum feeding) and 3, respectively. By the above argument, these results indicate that calf nutrient consumption during d 2 did not satisfy requirements relative to $\mathrm{d} 1$ when the $\mathrm{DM}$ feeding rate was lessened on average from 1.32 to $0.91 \% \mathrm{BW}$. The mean reduction in DM feeding rate was $31.9 \%$ as COL, MIX, and WM feeding rates were reduced by 20.0, 31.2, and $44.7 \%$ from d 1 to $\mathrm{d} 2$ and 3 . Conversely, the recovery in GLP-2 concentration during d 3 is peculiar as the DM feeding rate remained static relative to $\mathrm{d} 2$. To the authors' knowledge, the influence of time on plasma GLP-2 during a prolonged, imposed nutrient reduction, has not been investigated, making our findings novel but challenging to interpret.

However, it is possible that the appearance of GLP-2 in blood signals the degree to which energetic demands of the GIT are satisfied (Burrin et al., 2000; Castro et al., 2016), rather than satiation of whole-body energy requirements. On this basis, we theorize that the pattern in calf plasma GLP-2 between d 1, 2, and 3 signal the balance between energetic demand and satisfaction of the intestinal tract. The recovery in plasma GLP2 on $\mathrm{d} 3$ would then suggest retrogressive adaptation (Dierksen et al., 1985; Zhang et al., 2013; Pederzolli et al., 2018) of the GIT, most likely to conserve splanchnic energy expenditure (Reynolds, 2002). Retrogressive intestinal adaptation in response to reduced feed intake has been previously demonstrated in neonatal calves (Le Huerou et al., 1992; Guilloteau et al., 2009; Steinhoff-Wagner et al., 2015). Total small intestine and small intestine mucosa mass are noted to be 31.8 and $19.2 \%$ less, respectively, on d 2 than at birth (Le Huerou et al., 1992; Guilloteau et al., 2009). Similarly, mucosal villi size (but not crypt depth) decreased when 
calves were fed colostrum (milkings 1, 3, and 5; 5\% BW) for $4 \mathrm{~d}$ postnatal compared with term-born calves fed 1 meal of colostrum before slaughter at $26 \mathrm{~h}$ (Steinhoff-Wagner et al., 2015). Because calves in the study had decreased total energy consumption $(-1.83 \mathrm{Mcal})$ and reduced meal volume (19.8\% of average d 1 meal volume) during $\mathrm{d} 2$, it is plausible that energy consumption was inadequate relative to intestinal requirement. As gastrointestinal mass is affected by ME intake and feed-induced workload relative to requirements (McLeod and Baldwin, 2000; Reynolds, 2002; Hersom et al., 2004), the abrupt, combined exposure to these 2 factors and the phenotypic elasticity of neonates could cause rapid intestinal regression in calves within the current study. Consequently, GIT retrogressive adaption by d 3 would lessen the magnitude of imbalance between calf feed consumption and splanchnic energy expenditure (Reynolds, 2002), causing an apparent recovery of plasma GLP-2. However, the theory that plasma GLP-2 could signal splanchnic energy balance is currently speculation and the authors are unaware of any studies having addressed this notion.

\section{CONCLUSIONS}

Provision of COL for $3 \mathrm{~d}$ postnatal was anticipated to benefit small intestinal maturation to a greater extent than $3 \mathrm{~d}$ of MIX (intermediate) or WM feeding. Findings from this study indicate that no additional benefit is gained from COL than MIX feeding, though both had improved small intestine development compared with WM. Further, changes in serum IGF-1 and plasma GLP-2 were hypothesized to reflect intestinal development within treatments but are likely more related to total energy and nutrient consumption. The temporal decreases in IGF-1 and GLP-2 (the latter followed by recovery) are concerning as they suggest neonatal calves may consume insufficient quantities of nutrients by current industry practices. It is necessary to clarify neonatal calf metabolizable nutrient requirements relative to provision. For the present, study observations offer dairy producers the viable strategy of feeding neonatal calves transition milk or diluting colostrum with milk or milk replacer (after an initial colostrum meal) to promote intestinal development and function.

\section{ACKNOWLEDGMENTS}

The authors are grateful for the funding support provided by Alberta Livestock and Meat Agency Ltd. (Edmonton, AB, Canada), the Saskatoon Colostrum Co. Ltd. (Saskatoon, SK, Canada), Alberta Milk (Edmonton), SaskMilk (Regina, SK, Canada), BC Dairy Association (Burnaby, BC, Canada), Dairy Farmers of
Manitoba (Winnipeg, MB, Canada), Trouw Nutrition (Guelph, ON, Canada), Bayer Animal Health (Mississauga, ON, Canada), Lallemand (Montreal, QC, Canada), and the Natural Sciences and Engineering Research Council of Canada (Ottawa, ON, Canada). As well, the authors acknowledge the staff at the Dairy Research and Technology Centre (University of Alberta, Edmonton, AB, Canada) for technical assistance during the experiment. The authors have not stated any conflicts of interest.

\section{REFERENCES}

Baumrucker, C. R., and J. W. Blum. 1994. Effects of dietary recombinant human insulin-like growth factor on concentrations of hormones and growth factors in the blood of newborn calves. J. Endocrinol. 140:15-21. https://doi.org/10.1677/joe.0.1400015.

Berndtson, W. E. 1991. A simple, rapid and reliable method for selecting or assessing the number of replicates for animal experiments. J. Anim. Sci. 69:67-76. https://doi.org/10.2527/1991.69167x.

Blättler, U., H. Hammon, C. Morel, C. Philipona, A. Rauprich, V. Romé, I. Le Huërou-Luron, P. Guilloteau, and J. W. Blum. 2001. Feeding colostrum, its composition and feeding duration variably modify proliferation and morphology of the intestine and digestive enzyme activities of neonatal calves. J. Nutr. 131:1256-1263. https://doi.org/10.1093/jn/131.4.1256.

Blum, J. W. 2006. Nutritional physiology of neonatal calves. J. Anim. Physiol. Anim. Nutr. (Berl.) 90:1-11. https://doi.org/10.1111/j .1439-0396.2005.00614.x.

Blum, J. W., and C. R. Baumrucker. 2002. Colostral and milk insulinlike growth factors and related substances: Mammary gland and neonatal (intestinal and systemic) targets. Domest. Anim. Endocrinol. 23:101-110. https://doi.org/10.1016/S0739-7240(02)00149 -2 .

Blum, J. W., and H. Hammon. 2000. Colostrum effects on the gastrointestinal tract, and on nutritional, endocrine and metabolic parameters in neonatal calves. Livest. Prod. Sci. 66:151-159. https: //doi.org/10.1016/S0301-6226(00)00222-0.

Breier, B. H., and P. D. Gluckman. 1991. The regulation of postnatal growth: Nutritional influences on endocrine pathways and function of the somatotropic axis. Livest. Prod. Sci. 27:77-94. https://doi .org/10.1016/0301-6226(91)90047-T.

Brown, E. G., M. J. Vandehaar, K. M. Daniels, J. S. Liesman, L. T. Chapin, D. H. Keisler, and M. S. Weber Nielsen. 2005. Effects of increasing energy and protein intake on body growth and carcass composition of heifer calves. J. Dairy Sci. 88:585-594. https://doi .org/10.3168/jds.S0022-0302(05)72722-3.

Bühler, C., H. Hammon, G. L. Rossi, and J. W. Blum. 1998. Small intestinal morphology in eight-day-old calves fed colostrum for different durations or only in milk replacer and treated with long-R3insulin-like growth factor I and growth hormone. J. Anim. Sci. 76:758-765. https://doi.org/10.2527/1998.763758x.

Burrin, D., X. Guan, B. Stoll, Y. M. Petersen, and P. T. Sangild. 2003b. Glucagon-like peptide 2: A key link between nutrition and intestinal adaptation in neonates? J. Nutr. 133:3712-3716. https:/ /doi.org/10.1093/jn/133.11.3712.

Burrin, D. G. 1997. Is milk-borne insulin-like growth factor-I essential for neonatal development? J. Nutr. 127:975S-979S. https://doi .org/10.1093/jn/127.5.975S.

Burrin, D. G., B. Stoll, and X. Guan. 2003a. Glucagon-like peptide 2 function in domestic animals. Domest. Anim. Endocrinol. 24:103122. https://doi.org/10.1016/S0739-7240(02)00210-2.

Burrin, D. G., B. Stoll, R. Jiang, J. J. Holst, and P. J. Reeds. 2000. Minimal enteral nutrient requirements for intestinal growth in neonatal piglets: How much is enough? Am. J. Clin. Nutr. 71:16031610. https://doi.org/10.1093/ajcn/71.6.1603. 
Burrin, D. G., T. J. Wester, T. A. Davis, S. Amick, and J. P. Health. 1996. Orally administered IGF-I increases intestinal mucosa growth in formula-fed neonatal pigs. Am. J. Physiol. 270:R1085R1091. https://doi.org/10.1152/ajpregu.1996.270.5.R1085.

Castro, J. J., S. Y. Morrison, A. Hosseinni, J. J. Loor, J. K. Drackley, and I. R. Ipharraguerre. 2016. Secretion of glucagon-like peptide-2 responds to nutrient intake but not glucose provision in milk-fed calves. J. Dairy Sci. 99:5793-5807. https://doi.org/10.3168/jds 2015-10519

Davis, T. A., D. G. Burrin, M. L. Fiorotto, and H. V. Nguyen. 1996. Protein synthesis in skeletal muscle and jejunum is more responsive to feeding in 7- than 26-day-old pigs. Am. J. Physiol. 270:E802E809. https://doi.org/10.1152/ajpendo.1996.270.5.E802.

Dierksen, G. L., H. G. Liebich, and E. Mayer. 1985. Adaptive changes of the ruminal mucosa and functional and clinical significance. Bov. Pract. 20:116-120.

Donovan, S. M., J. C.-J. Chao, R. T. Zijlstra, and J. Odle. 1997. Orally administered iodinated recombinant human insulin-like growth factor-I (125I-rhIGF-I) is poorly absorbed by the newborn piglet. J. Pediatr. Gastroenterol. Nutr. 24:174-182. https://doi.org/10 .1097/00005176-199702000-00011.

Dubé, P. E., C. L. Forse, J. Bahrami, and P. L. Brubaker. 2006. The essential role of insulin-like growth factor-1 in the intestinal tropic effects on glucagon-like peptide-2 in mice. Gastroenterology 131:589-605. https://doi.org/10.1053/j.gastro.2006.05.055.

Egli, C. P., and J. W. Blum. 1998. Clinical, haemetological, metabolic and endocrine traits during the first three months of life of suckling Simmentaler calves held in a cow-calf operation. J. Vet. Med. A Physiol. Pathol. Clin. Med. 45:99-118. https://doi.org/10.1111/ j.1439-0442.1998.tb00806.x.

Elsabagh, M., Y. Inabu, T. Obitsu, and T. Sugino. 2017. Response of plasma glucagon-like peptide-2 to feeding pattern and intraruminal administration of volatile fatty acids in sheep. Domest. Anim. Endocrinol. 60:31-41. https://doi.org/10.1016/j.domaniend.2017 .03 .001 .

Fischer, A. J., Y. Song, Z. He, D. M. Haines, L. L. Guan, and M. A. Steele. 2018. Effect of delaying colostrum feeding on passive transfer and intestinal bacterial colonization in neonatal male Holstein calves. J. Dairy Sci. 101:3099-3109. https://doi.org/10.3168/jds 2017-13397.

Georgiev, I. P., T. M. Georgieva, M. Pfaffl, H. M. Hammon, and J. W. Blum. 2003. Insulin-like growth factor and insulin receptors in intestinal mucosa of neonatal calves. J. Endocrinol. 176:121-132. https://doi.org/10.1677/joe.0.1760121.

Greenwood, P. L., A. S. Hunt, R. M. Slepetis, K. D. Finnerty, C. Alston, D. H. Beermann, and A. W. Bell. 2002. Effects of birth weight and postnatal nutrition on neonatal sheep: III. Regulation of energy metabolism. J. Anim. Sci. 80:2850-2861. https://doi .org/10.2527/2002.80112850x.

Guilloteau, P., I. Le Huëron-Luron, R. Toullec, J. A. Chayvialle, R. Zabiekski, and J. W. Blum. 1997. Gastrointestinal regulatory peptides and growth factors in young cattle and sheep. J. Vet. Med. A Physiol. Pathol. Clin. Med. 44:1-23. https://doi.org/10.1111/j .1439-0442.1997.tb01082.x.

Guilloteau, P., R. Zabielski, and J. W. Blum. 2009. Gastrointestinal tract and digestion in the young ruminant: Ontogenesis, adaptations, consequences and manipulations. J. Physiol. Pharmacol. 60(Suppl. 3):37-46.

Hadorn, U., H. Hammon, R. Bruckmaier, and J. W. Blum. 1997. Delaying colostrum intake by one day has important effects on metabolic traits and on gastrointestinal and metabolic hormones in neonatal calves. J. Nutr. 127:2011-2023. https://doi.org/10.1093/ jn/127.10.2011.

Hall, P. A., D. A. Levison, A. L. Woods, C. C. Yu, D. B. Kellock, J. A. Watkins, D. M. Barnes, C. E. Gillett, R. Camplejohn, R. Dover, N. H. Waseem, and D. P. Lane. 1990. Proliferating cell nuclear antigen (PCNA) immunolocalization in paraffin sections: An index of cell proliferation with evidence of deregulated expression in some neoplasms. J. Pathol. 162:285-294. https://doi.org/10.1002/ path.1711620403.
Hammon, H., and J. W. Blum. 1997. The somatotropic axis in neonatal calves can be modulated by nutrition, growth hormone, and Long-R3-IGF-I. Am. J. Physiol. 273:E130-E138. https://doi.org/ 10.1152/ajpendo.1997.273.1.E130.

Hammon, H. M., G. Schiessler, A. Nussbaum, and J. W. Blum. 2002. Feed intake patterns, growth performance, and metabolic traits in calves fed unlimited amounts of colostrum and automate, starting in the neonatal period. J. Dairy Sci. 85:3352-3362. https://doi .org/10.3168/jds.S0022-0302(02)74423-8.

Hammon, H. M., I. A. Zanker, and J. W. Blum. 2000. Delayed colostrum feeding affects IGF-I and insulin plasma concentrations in neonatal calves. J. Dairy Sci. 83:85-92. https://doi.org/10.3168/ jds.S0022-0302(00)74859-4.

Hersom, M. J., C. R. Krehbiel, and G. W. Horn. 2004. Effect of live weight gain of steers during winter grazing: II. Visceral organ mass, cellularity, and oxygen consumption. J. Anim. Sci. 82:184197. https://doi.org/10.2527/2004.821184x.

Holst, J. J., J. Christiansen, and C. Kuhl. 1976. The enteroglucagon response to intrajejunal infusion of glucose, triglycerides, and sodium chloride, and its relation to jejunal inhibition of gastric acid secretion in man. Scand. J. Gastroenterol. 11:297-304.

Inabu, Y., A. Fischer, Y. Song, L. L. Guan, M. Oba, M. A. Steele, and T. Sugino. 2018. Short communication: The effect of delayed colostrum feeding on plasma concentrations of glucagon-like peptide 1 and 2 in newborn calves. J. Dairy Sci. 101:6627-6631. https://doi .org/10.3168/jds.2018-14412.

Inabu, Y., J. Pyo, S. Pletts, L. L. Guan, M. A. Steele, and T. Sugino, 2019. Effect of extended colostrum feeding on plasma glucagon-like peptide (GLP)-1 concentration in newborn calves. J. Dairy Sci 102:4619-4627. https://doi.org/10.3168/jds.2018-15616.

Inabu, Y., A. Saegusa, K. Inouchi, S. Koike, M. Oba, and T. Sugino. 2017. Plasma concentrations of glucagon-like peptide 1 and 2 in calves fed starters containing lactose. J. Dairy Sci. 100:9361-9371. https://doi.org/10.3168/jds.2017-12910.

Kisielinski, K., S. Willis, A. Prescher, B. Klosterhalfen, and V. Schumpelick. 2002. A simple new method to calculate small intestine absorptive surface in the rat. Clin. Exp. Med. 2:131-135. https://doi.org/10.1007/s102380200018.

Le Huerou, I., P. Guilloteau, C. Wicker, A. Mouats, J.-A. Chayvialle, C. Bernard, J. Burton, R. Toullec, and A. Puigserver. 1992. Activity distribution of seven digestive enzymes along small intestine in calves during development and weaning. Dig. Dis. Sci. 37:40-46. https://doi.org/10.1007/BF01308340.

Leen, J. L. S., A. Izzo, C. Upadhyay, K. J. Rowland, P. E. Dubé, S. Gu, S. P. Heximer, C. J. Rhodes, D. R. Storm, P. K. Lund, and P. L. Brubaker. 2011. Mechanism of action of glucagon-like peptide-2 to increase IGF-I mRNA in intestinal subepithelial fibroblasts. Endocrinology 152:436-446. https://doi.org/10.1210/en.2010-0822.

MacDonald, R. S. 1999. The role of insulin-like growth factors in small intestinal cell growth and development. Horm. Metab. Res. 31:103-113. https://doi.org/10.1055/s-2007-978706.

Malmuthuge, N., Y. Chen, G. Liang, L. A. Goonewardene, and L. L. Guan. 2015. Heat-treated colostrum feeding promotes beneficial bacteria colonization in the small intestine of neonatal calves. J. Dairy Sci. 98:8044-8053. https://doi.org/10.3168/jds.2015-9607.

McGrath, B. A., P. F. Fox, P. L. H. McSweeney, and A. L. Kelly. 2016. Composition and properties of bovine colostrum: a review. Dairy Sci. Technol. 96:133-158. https://doi.org/10.1007/s13594 $-015-0258-x$.

McGuire, M. A., D. A. Dwyer, R. J. Harrell, and D. E. Bauman. 1995. Insulin regulates circulating insulin-like growth factors and some of their binding proteins in lactating cows. Am. J. Physiol. 269:E723E730. https://doi.org/10.1152/ajpendo.1995.269.4.E723.

McLeod, K. R., and R. L. Baldwin VI. 2000. Effects of diet forage: concentrate ratio and metabolizable energy intake on visceral organ growth and in vitro oxidative capacity of gut tissues in sheep. J. Anim. Sci. 78:760-770. https://doi.org/10.2527/2000.783760x.

Ontsouka, E. C., C. Albrecht, and R. M. Bruckmaier. 2016. Invited Review: Growth-promoting effects of colostrum in calves based on interaction with intestinal cell surface receptors and receptor-like 
transporters. J. Dairy Sci. 99:4111-4123. https://doi.org/10.3168/ jds.2015-9741.

Pakkanen, R. J., and J. Aalto. 1997. Growth factors and antimicrobial factors of bovine colostrum: A review. Int. Dairy J. 7:285-297. https://doi.org/10.1016/S0958-6946(97)00022-8.

Pederzolli, R. A., A. G. Van Kessel, J. Campbell, S. Hendrick, K. M. Wood, and G. B. Penner. 2018. Effect of ruminal acidosis and short-term low feed intake on indicators of gastrointestinal barrier function in Holstein steers. J. Anim. Sci. 96:108-125. https://doi .org/10.1093/jas/skx049.

Petersen, Y. M., B. Hartmann, J. J. Holst, I. Le Huerou-Luron, C. R. Bjørnvad, and P. T. Sangild. 2003. Introduction of enteral food increase plasma GLP-2 and decreases GLP-2 receptor mRNA and abundance during pig development. J. Nutr. 133:1781-1786. https: //doi.org/10.1093/jn/133.6.1781.

Quigley, J. D., T. A. Wolfe, and T. H. Elsasser. 2006. Effects of additional milk replacer feeding on calf health, growth and selected blood metabolites in calves. J. Dairy Sci. 89:207-216. https://doi .org/10.3168/jds.S0022-0302(06)72085-9.

Rauprich, A. B. E., H. M. Hammon, and J. W. Blum. 2000. Effects of feeding colostrum and a formula with nutrient contents as colostrum on metabolic and endocrine traits in neonatal calves. Biol. Neonate 78:53-64. https://doi.org/10.1159/000014247.

Reynolds, C. K. 2002. Economics of visceral energy metabolism in ruminants: Toll keeping or internal revenue service? J. Anim. Sci. 80(Suppl. 2):E74-E84. https://doi.org/10.2527/animalsci2002.80E -Suppl_2E74x.

Ronge, H., and J. W. Blum. 1988. Somatomedin C and other hormones in dairy cows around parturition, in newborn calves and in milk. J. Anim. Physiol. Anim. Nutr. 60:168-176. https://doi.org/ 10.1111/j.1439-0396.1988.tb00190.x.

Rowland, K. J., S. Trivedi, D. Lee, K. Wan, R. N. Kulkarni, M. Holzenberger, and P. L. Brubaker. 2011. Loss of glucagon-like peptide-2 induced proliferation following intestinal epithelial insulinlike growth factor-1 receptor deletion. Gastroenterology 141:21662175. https://doi.org/10.1053/j.gastro.2011.09.014.

Schäff, C. T., D. Rohrbeck, J. Steinhoff-Wagner, E. Kanitz, H. Sauerwein, R. M. Bruckmaier, and H. M. Hammon. 2014. Effects of colostrum versus formula feeding on hepatic glucocorticoid and $\alpha 1$ - and $\beta 2$-adrenergic receptors in neonatal calves and their effect on glucose and lipid metabolism. J. Dairy Sci. 97:6344-6357. https: //doi.org/10.3168/jds.2014-8359.

Shen, Z., H.-M. Seyfert, B. Löhrke, F. Schneider, R. Zitnan, A. Chudy, S. Kuhla, H. M. Hammon, J. W. Blum, H. Martens, H. Hagemeister, and J. Voigt. 2004. An energy-rich diet causes rumen papillae proliferation associated with more IGF Type 1 receptors and increased plasma IGF-1 concentrations in young goats. J. Nutr. 134:11-17. https://doi.org/10.1093/jn/134.1.11.

Shivley, C. B., J. E. Lombard, N. J. Urie, D. M. Haines, R. Sargent, C. A. Kopral, T. J. Earleywine, J. D. Olson, and F. B. Garry. 2018. Preweaned heifer management on US dairy operations: Part II. Factors associated with colostrum quality and passive transfer status of dairy heifer calves. J. Dairy Sci. 101:9185-9198. https:// doi.org/10.3168/jds.2017-14008.

Smith, J. M., M. E. Van Amburgh, M. C. Diaz, M. C. Lucy, and D. E. Bauman. 2002. Effect of nutrient intake on the development of the somatotropic axis and its responsiveness to GH in Holstein bull calves. J. Anim. Sci. 80:1528-1537. https://doi.org/10.2527/ 2002.8061528x.

Steinhoff-Wagner, J., S. Görs, P. Junghans, R. M. Bruckmaier, E. Kanitz, C. M. Metges, and H. M. Hammon. 2011. Intestinal glucose absorption but not endogenous glucose production differs between colostrum- and formula-fed neonatal calves. J. Nutr. 141:4855. https://doi.org/10.3945/jn.110.128652.

Steinhoff-Wagner, J., U. Schönhusen, R. Zitnan, M. Hudakova, H. Pfannkuche, and H. Hammon. 2015. Ontogenic changes of villus growth, lactase activity, and intestinal glucose transporters in preterm and term born calves with or without prolonged colostrum feeding. PLoS One 10:e0128154. https://doi.org/10.1371/journal pone.0128154.

Steinhoff-Wagner, J., R. Zitnan, U. Schönhusen, H. Pfannkuche, M. Hudakova, C. Metges, and H. M. Hammon. 2014. Diet effects on glucose absorption in the small intestine of neonatal calves: Importance of intestinal mucosal growth, lactase activity, and glucose transporters. J. Dairy Sci. 97:6358-6369. https://doi.org/10.3168/ jds.2014-8391.

Stoll, B., X. Chang, R. Jiang, J. B. Van Goudoever, P. J. Reeds, and D. G. Burrin. 2000. Enteral carbohydrate and lipid inhibit small intestinal proteolysis in neonatal pigs. FASEB J. 14:A558.

Sugino, T., Y. Hasegawa, Y. Kurose, M. Kojima, K. Kangawa, and Y. Terashima. 2004. Effects of ghrelin on food intake and neuroendocrine function in sheep. Anim. Reprod. Sci. 82-83:183-194. https: //doi.org/10.1016/j.anireprosci.2004.05.001.

Thissen, J.-P., J.-M. Ketelslegers, and L. E. Underwood. 1994. Nutritional regulation of insulin-like growth factors. Endocr. Rev. 15:80-101. https://doi.org/10.1210/edrv-15-1-80.

Urie, N. J., J. E. Lombard, C. B. Shivley, C. A. Kopral, A. E. Adams, T. J. Earleywine, J. D. Olson, and F. B. Garry. 2018. Preweaned heifer management on US dairy operations: Part V. Factors associated with morbidity and mortality in preweaned dairy heifer calves. J. Dairy Sci. 101:9229-9244. https://doi.org/10.3168/jds .2017-14019.

Vacher, P.-Y., G. Bestetti, and J. W. Blum. 1995. Insulin-like growth factor I absorption in the jejunum of neonatal calves. Biol. Neonate 68:354-367. https://doi.org/10.1159/000244256.

Winder, C. B., C. A. Bauman, T. F. Duffield, H. W. Barkema, G. P. Keefe, J. Dubuc, F. Uehlinger, and D. F. Kelton. 2018. Canadian National Dairy Study: Heifer calf management. J. Dairy Sci. 101:10565-10579. https://doi.org/10.3168/jds.2018-14680.

Wongdee, K., J. Teerapornpuntakit, C. Sripong, A. Longkunan, W. Chankamngoen, C. Keadsai, K. Kraidith, N. Krishnamra, and N. Charoenphandhu. 2016. Intestinal mucosal changes and upregulated calcium transporter and FGF-23 expression during lactation: Contribution of lactogenic hormone prolactin. Arch. Biochem. Biophys. 590:109-117. https://doi.org/10.1016/j.abb.2015.11.038.

Xiao, Q., R. P. Boushey, D. J. Drucker, and P. L. Brubaker. 1999 Secretion of the intestinotropic hormone glucagon-like peptide 2 is differentially regulated by nutrients in humans. Gastroenterology 117:99-105. https://doi.org/10.1016/S0016-5085(99)70555-X.

Yang, M., Y. Zou, Z. H. Wu, S. L. Li, and Z. J. Cao. 2015. Colostrum quality affects immune system establishment and intestinal development of neonatal calves. J. Dairy Sci. 98:7153-7163. https://doi .org/10.3168/jds.2014-9238.

Zabielski, R., M. M. Godlewski, and P. Guilloteau. 2008. Control of development of gastrointestinal system in neonates. J. Physiol. Pharmacol. 59:35-54.

Zhang, S., J. R. Aschenbach, D. R. Barreda, and G. B. Penner. 2013. Recovery of absorptive function of the reticulo-rumen and total tract barrier function in beef cattle after short-term feed restriction. J. Anim. Sci. 91:1696-1706. https://doi.org/10.2527/jas.2012 -5774 .

\section{ORCIDS}

J. Pyo ৫ https://orcid.org/0000-0002-2111-0968

S. Pletts @ https://orcid.org/0000-0002-2167-9636

T. Sugino (® https://orcid.org/0000-0001-5502-3451

L. L. Guan (๑ https://orcid.org/0000-0002-8420-4371

M. Steele 잔 https://orcid.org/0000-0001-6941-6205 